\title{
Comparative study of silicon and selenium to modulate chloroplast pigments levels, Hill activity, photosynthetic parameters and carbohydrate metabolism under arsenic stress in rice seedlings
}

\author{
Susmita Das \\ University of Calcutta \\ Asok K. Biswas ( $\square$ dr.asokbiswas25@gmail.com ) \\ University of Calcutta
}

\author{
Research Article \\ Keywords: Arsenic, rice, silicon, selenium, chlorophyll, photosynthesis, Licor, carbohydrate metabolism. \\ Posted Date: July 20th, 2021 \\ DOI: https://doi.org/10.21203/rs.3.rs-241077/v1 \\ License: (c) (i) This work is licensed under a Creative Commons Attribution 4.0 International License. Read Full License
}

Version of Record: A version of this preprint was published at Environmental Science and Pollution Research on October 31st, 2021. See the published version at https://doi.org/10.1007/s11356-021-16836-5. 


\section{Abstract}

Arsenic (As) in groundwater severely harms global economic development by affecting growth and productivity of agricultural crops that causes human health risk. The comparative influence of silicon (Si) and selenium (Se) to modulate pigments levels, photosynthetic parameters using LI6400XT Portable Photosynthesis System and carbohydrate metabolism under arsenate (As-V) stress in rice cv. MTU-1010 were evaluated. As(V) stress significantly decreased chlorophyll-a (32\% on an average), chlorophyll-b (58\% on an average), total chlorophyll (46\% on an average), fluorescence intensity ( $31 \%$ on an average), , carotene (39\% on an average), xanthophyll (33\% on an average), Hill activity (47\% on an average) and the photosynthetic parameters viz., intercellular- $\mathrm{CO}_{2}$-concentration ( $52 \%$ on an average), net photosynthesis ( $54 \%$ on an average), transpiration rate (36\% on an average) and stomatal conductance (38\% on an average) in the test seedlings. As(V) + Si treatments enhanced the said parameters more than $\mathrm{As}(\mathrm{V})+$ Se treatments in rice seedlings. Sugar contents viz., reducing (85\% on an average) and non-reducing sugar (61\% on an average) were increased but starch content (57\% on an average) was decreased in As(V) treated seedlings. The activities of carbohydrate metabolizing enzymes were increased, while sucrose synthase activity was decreased due to As(V) toxicity in the test seedlings. Co-application of Si and As(V) as well as Se and $\mathrm{As}(\mathrm{V})$ showed ameliorative effects on the said parameters but more potential effect was observed under combined application of $\mathrm{Si}$ and $\mathrm{As}(\mathrm{V})$ in rice seedlings. Thus, the present study is focused to highlight the comparative capability of Si and Se to ameliorate the As induced toxic effects on chloroplast pigments, photosynthetic activities and sugar metabolism in rice seedlings which will be an effective approach to develop possible strategies in As contaminated agricultural soil to improve normal growth and productivity of rice plants.

\section{Introduction}

Arsenic is a carcinogenic metalloid with the symbol 'As' and atomic number '33'. This phytotoxic metalloid, found naturally in soils (Smedley and Kinniburgh, 2002) belonging to Group 15 or V-A in the periodic table, and can exists in four oxidation states: (-3), 0, (+3) and (+5). Arsenite (As-III) and arsenate (As-V) are the two predominant oxidation states (WHO, 2001; IARC, 2004) of which As(III) is more toxic than As(V) for both humans and plants (Zhao et al., 2009). As toxicity inhibits various kinds of physiological as well as biochemical metabolisms in plant cells among those most severe conditions may occur during photosynthesis (Anjum et al., 2017; Srivastava et al., 2013). Rice is the major crop for nutrition in PanAsiatic countries consumed worldwide by humans. Rice cv. MTU-1010, possesses high yielding capacity and extensive amount of groundwater is needed for crop irrigation. So, As could easily get accumulated in different tissues including grains of the test cultivar by As polluted groundwater.

Silicon (Si), a trace element present in the soil, belongs to Group 14 or IV-A in the periodic table. Plants can absorb Si as uncharged silicic acid $\left(\mathrm{H}_{4} \mathrm{SiO}_{4}\right)$. Si possesses the ability to reduce the stress induced toxic effects during Al, $\mathrm{Cd}$ and $\mathrm{Zn}$ stress in rice (Singh et al., 2011). The Si mediated transporter, $L$ si1, is a member of NIP subfamily that helps to transport Si in plant cells (Mitani et al. 2008). There is another transporter $L$ si2, known to efflux Si/As(III) towards xylem in plants (Zhao et al. 2009). According to Wattanapayapkul et al. (2011), Si fertilization is beneficial for plants. Therefore, Si administration will be a low-cost approach to combat As induced toxicity by lessening As uptake and accumulation within plant cells. In our previous study, we also reported that in the presence of Si, As accumulation was reduced in rice seedlings (Das et al. 2018).

Selenium (Se) is a trace element and a Group 16 or VI-A metalloid in the periodic table. Se prevails in nature as both inorganic forms viz., selenate $\left(\mathrm{SeO}_{4}{ }^{2-}\right)$, selenite $\left(\mathrm{SeO}_{3}{ }^{2-}\right)$, selenide $\left(\mathrm{Se}^{2-}\right)$, elemental Se and organic forms viz., Selenocysteine (SeCys) and Selenomethionine (SeMet) (Wu et al., 2015). $\mathrm{SeO}_{4}{ }^{2-}$ is the most ubiquitous form of bioavailable $\mathrm{Se}$ in agricultural fields as well as more water soluble than $\mathrm{SeO}_{3}{ }^{2-}\left(\mathrm{Missana}{ }^{2} \mathrm{al}_{\text {., }}\right.$ 2009). In previous studies, it has been demonstrated that at low concentration $(0 \mu \mathrm{M}-5 \mu \mathrm{M})$, Se has the ability to protect plants from various environmental stresses viz., cold (Chu et al., 2010), drought (Hasanuzzaman and Fujita, 2011) and also metal stresses (Kumar et al., 2012; Pandey and Gupta, 2015). Generally, Se concentration lower than $1 \mathrm{mg} \mathrm{Kg}^{-1}$ in soils can enhance plant growth in non-accumulating plants. Se increases plant resistance against oxidative stress caused by generation of free radicals in soybean (Djanaguiraman et al., 2005). As(V) uptake in Pteris vittata was suppressed by the addition of Se, indicating the antagonistic effects of selenium on arsenate uptake (Feng et al., 2009). Se application in the form of fertilizer will be a low-cost way to reduce the toxicity in rice grown in arsenic prone soil due to its antagonistic nature.

In chloroplast, chlorophylls operate photosynthesis by assimilating and converting light energy into chemical energy to drive all kinds of cellular activities. But the formation and activation of this pigment is suppressed under stress induced oxidative difficulties in the environment (Agathokleous et al., 2020). There is another pigment, carotenoids provide defence to chlorophyll during biotic and abiotic stresses (Drezkiewica and Basznzki, 2010). They have photoprotective role and protect the photosynthetic machinery from the harmful effects of free radicals. As stress impedes the biogenesis of chlorophyll that let down the potency of PS-II and thus interrupts the photosynthesis process (Bankaji et al., 2014). This metalloid contamination restricts the stomatal gateway from entering the $\mathrm{CO}_{2}$ which is correlated with the depletion in transpiration rate as there is limitation of gas interchange from environment to plants (Milivojevic et al., 2006; Anjum et al., 2016). If the stomata have been closed for a long time, water levels and its potentiality are being enhanced which results in the reduction of photosynthesis (Ohashi et al., 2006). In some previous reports, it was demonstrated that Si application enhanced the rate of photosynthesis in wild type rice plant (Sanglard et al., 2014). Sil et al., (2019) also reported that Si was able to improve photosynthetic activity under As stress in wheat seedlings. On the other side, Se reduced the generation of oxidative stress by alleviating malondialdehyde levels and elevated the photosynthetic activity as well as accumulation of sugars in Solanum tuberosum L. cv. Sante under both As and Cd stresses (Sahid et al., 2019). Therefore, the present investigation is emphasized on the comparative 
effect of Si and Se to lessen As induced toxicity on the basis of pigment levels, photosynthetic parameters and carbohydrate metabolism in hydroponically grown rice seedlings.

A seedling in flourishing stage generally face endangered situations concerning instability of carbohydrates in the cells which is a perfect phase to examine the impact during biotic and abiotic stresses (Hanley and May, 2005). During photosynthesis, plants promote carbohydrate production which is carried out to different parts in the form of soluble sugars or stored in the form of starch and sugar. It was demonstrated in the report of Rosa et al., (2009) that the growth and development of plant seeds to seedlings stage is fundamentally rely on carbohydrate storage that is transported to different plant parts from the repository organ which is essential to balance an osmotic equilibrium in plants. Higher levels of photosynthetic products in plant tissue can maintain the proficiency of plants to revive them under various kinds of environmental stresses (Bagheri and Sadeghipour, 2009; Naureen and Naqvi, 2010). Accumulation of sugars under metal toxicity predominantly protect the concentration of amino acids, nucleic acids, proteins and also provides osmo-protection in the plant cell. Assimilated carbon produce sugar which can modulate toxicity level as well as gene regulation during environmental stresses (Lemoine et al., 2013). Joint application of As(V) with Si and As(V) with Se was an attempt to reduce the metal induced toxic effects by improving pigment levels, photosynthetic parameters and regulating carbohydrate metabolism to develop tolerance against toxicity.

In the present study, we have documented how exogenous Si and Se amendments are individually potential to improve the chloroplast pigments level, photosynthetic parameters and carbohydrate metabolic processes in rice cv. MTU-1010 seedlings during As(V) application. The current study will assist to develop some techniques in soil condition which will be a low-cost way to cultivate rice with improved growth and yield in As subdued agricultural soils.

\section{Material And Methods}

\subsection{Plant material and chemical treatments}

Rice seeds, collected from the State Agricultural Rice Research Station, Chinsurah, Hooghly, West Bengal, were sterilized with $5 \%$ NaOCl solution and washed with distilled water. 50 seeds for each treatment were spread over in petridishes ( $11 \mathrm{~cm}$ in diameter) lined with filter papers containing water, incubated at $37^{\circ} \mathrm{C}$ for three days in dark for germination ( 2 replicates for each treatment, 24 petridishes for root and 24 petridishes for shoot for each experiment). The germinated seeds were transferred to petridishes lined with filter papers containing $25 \mu \mathrm{M}, 50 \mu \mathrm{M}$ and $75 \mu \mathrm{M}$ sodium arsenate $\left(\mathrm{Na}_{2} \mathrm{HAsO}_{4} \cdot 7 \mathrm{H}_{2} \mathrm{O}\right.$; Loba-Chemie, India) solutions (w/v) with or without $2 \mathrm{mM}$ sodium silicate $\left(\mathrm{Na}_{2} \mathrm{SiO}_{3} \cdot 9 \mathrm{H}_{2} \mathrm{O}\right.$; Loba-Chemie, India) and 5 $\mu \mathrm{M}$ sodium selenate $\left(\mathrm{Na}_{2} \mathrm{SeO}_{4}\right.$; Loba-Chemie, India) along with modified Hoagland solution (pH 6.5) (Hoagland and Arnon, 1950) for 3 weeks between $25^{\circ} \mathrm{C}$ to $28^{\circ} \mathrm{C}$ temperature under $16 \mathrm{~h}$ photoperiod $\left(260 \mu \mathrm{mol} \mathrm{m} \mathrm{m}^{-2} \mathrm{~s}^{-1} \mathrm{PFD}\right)$. The control set was composed of only modified Hoagland solution. In every alternate day, fresh solutions were added in each treatment with pH adjustment. Then the seedlings were harvested, roots and shoots were separated for the following studies.

\subsection{Estimation of chlorophyll contents and its fluorescence intensity}

Plant leaves of $1 \mathrm{~g}$ obtained from each treatment was chopped finely and extracted in $20 \mathrm{ml} 80 \%(\mathrm{v} / \mathrm{v})$ alkaline $\left(0.1 \mathrm{M} \mathrm{Na}_{2} \mathrm{CO}_{3}\right)$ acetone. The chlorophyll contents were estimated at $645 \mathrm{~nm}$ and $663 \mathrm{~nm}$ respectively and calculated by following the formula described by Arnon (1949). The fluorescence intensity of the chlorophyll was tracked at an excitation wavelength $640 \mathrm{~nm}$ and an emission wavelength $680 \mathrm{~nm}$ by using a Hitachi650-40 spectrofluorometer and expressed as mg chlorophyll g ${ }^{-1} \mathrm{FW}$.

Chlorophyll-a: $\left[\left(O D_{663}-O D_{645}\right) \times V / 1000 \times 1 / W\right]$

Chlorophyll-b: $\left[\left(O D_{645}-O D_{663}\right) \times V / 1000 \times 1 / W\right]$

Total chlorophyll: [(OD $\left.\left.645+O D_{663}\right) \times V / 1000 \times 1 / W\right]$

where, $\mathrm{OD}=$ Optical Density

$V=($ Final volume of $80 \%$ alkaline acetone - chlorophyll extract $)$

$\mathrm{W}=$ Fresh weight of leaves (here, $1 \mathrm{~g}$ )

\subsection{Estimation of carotenoid contents}

Carotene and xanthophyll contents were measured by following the method of Davies (1965). Pigmented alkaline acetone solution was mixed with $20 \mathrm{ml}$ cyclohexane in a separating funnel. The hexane layer was washed and xanthophyll was separated from the upper hexane layer containing carotene by extracting it with $20 \mathrm{ml} 90 \%$ (v/v) methanol. Carotene and xanthophyll contents were estimated at $425 \mathrm{~nm}$ and $450 \mathrm{~nm}$ respectively.

The said contents were expressed as optical density $\mathrm{g}^{-1} \mathrm{FW}$.

\subsection{Estimation of Hill activity}

Page 3/21 
Hill activity was estimated by following the method of Vishniac (1957). Plant leaves of $1 \mathrm{~g}$ obtained from each treatment was crushed in $5 \mathrm{ml}$ sucrose phosphate buffer $(0.5 \mathrm{M}$ sucrose in $0.05 \mathrm{M}$ sodium phosphate buffer, $\mathrm{pH} 6.2)$ and centrifuged at $1,000 \mathrm{~g}$ at $4^{\circ} \mathrm{C}$ for $10 \mathrm{mins}$. The supernatant was collected and re-centrifuged at $5,000 \mathrm{~g}$ at $4^{\circ} \mathrm{C}$ for $15 \mathrm{mins}$. Chloroplast suspension was prepared by dissolving pellets obtained after centrifugation in $5 \mathrm{ml}$ sucrose-phosphate buffer. Reaction mixture containing $1 \mathrm{ml}$ chloroplast suspension, $4 \mathrm{ml}$ sucrose phosphate buffer and $0.5 \mathrm{ml} 0.03 \%$ DCPIP was kept under bright sunlight for 30 mins after recording initial absorbance at $610 \mathrm{~nm}$, followed by measuring the absorbance of discolored solution. Differences in OD values were recorded. The activity was calculated from a standard curve prepared with known concentration of DCPIP and expressed as $\mu \mathrm{g}$ DCPIP reduced $\mathrm{g}^{-1}$ chlorophyll $\mathrm{hr}^{-1}$.

\subsection{Estimation of photosynthetic parameters}

Photosynthetic parameters in terms of internal $\mathrm{CO}_{2}$ concentration $\left(C_{i}\right)$, net photosynthesis $\left(P_{n}\right)$, transpiration rate $\left(T_{r}\right)$ and stomatal conductance $\left(G_{S}\right)$ were estimated from intact fully stretched leaves by using Infrared Gas Analyzer (IRGA) portable photosynthetic system (Li-COR 6400, NE, and USA) having an attached LED light source (6400-02B) (Biswas et al., 2013). The experiment was conducted between 8 am to 11 am. The environmental conditions viz., air temperature $\left(25^{\circ} \mathrm{C}\right)$, relative humidity $(85 \%)$, PPFD $\left(900 \mu \mathrm{mol} \mathrm{mol} \mathrm{m}^{-2} \mathrm{~s}^{-1}\right)$ and $\mathrm{CO}_{2} \mathrm{concentration}\left(300 \mu \mathrm{mol} \mathrm{mol}{ }^{-}\right.$

1) were maintained throughout the experiment.

\subsection{Estimation of carbohydrate contents}

\subsubsection{Reducing and non-reducing sugar contents}

Reducing sugar contents was estimated according to Miller (1972). Plant samples of $1 \mathrm{~g}$ obtained from each treatment was crushed in $5 \mathrm{ml} 80 \%$ ( $\mathrm{v} / \mathrm{v}$ ) ethanol and centrifuged at 2,000 g for 20 mins. The supernatant was collected and mixed with 0.5 ml 1\% DNSA (3,5-dinitrosalicylic acid) reagent. The mixture was kept in boiling water-bath for 5 mins. After incubation the reducing sugar contents was measured at $515 \mathrm{~nm}$. Reducing sugar content was calculated from a standard curve of glucose and data was expressed as $\mathrm{mg} \mathrm{g}^{-1} \mathrm{FW}$.

Total soluble sugar contents was estimated by phenol sulphuric acid reagent method according to Dubois et al., (1956). Plant sample of $1 \mathrm{~g}$ from each treatment was homogenized in $5 \mathrm{ml} 80 \%$ ethanol. It was centrifuged at 2,000 g for 20 mins. Reaction mixture containing $1 \mathrm{ml}$ supernatant, 5 $\mathrm{ml}$ conc. $\mathrm{H}_{2} \mathrm{SO}_{4}$ and $0.05 \mathrm{ml} 5 \%$ phenol solution was incubated in water-bath at $30^{\circ} \mathrm{C}$ for 20 mins. A yellow-orange color was developed in the solution and measured at $490 \mathrm{~nm}$. The said content was calculated from a standard curve and expressed as $\mathrm{mg} \mathrm{g}^{-1} \mathrm{FW}$. Non-reducing sugar contents was estimated by subtracting the value of reducing sugar from the values of total sugar and expressed as $\mathrm{mg} \mathrm{g}^{-1} \mathrm{FW}$.

\subsubsection{Starch contents}

The remaining pellet obtained during the estimation of total soluble sugar, was suspended in $2.5 \mathrm{ml}$ distilled $\mathrm{H}_{2} \mathrm{O}$ to measure starch contents (McCready et al., 1950). The resultant suspension was mixed with $3.25 \mathrm{ml} 52 \% \mathrm{HClO}_{4}$ and stirred continuously. The mixture was centrifuged at $2,000 \mathrm{~g}$ for 20 mins and supernatant was collected. The final volume of supernatant was made $50 \mathrm{ml}$ by adding distilled water and filtered by using Whatman (No. 42) filter paper. To estimate starch contents $1 \mathrm{ml}$ filtrate was taken and measured following the method used for total soluble sugar contents. The starch contents was estimated in terms of glucose and 0.9 factor was used for the conversion of glucose to starch. Data was expressed as $\mathrm{mg} \mathrm{g}^{-1} \mathrm{FW}$.

\subsection{Assay of carbohydrate metabolizing enzymes}

\subsubsection{Sucrose synthase (SS; EC 2.4.1.13) and Sucrose phosphate synthase (SPS; EC 2.4.1.14) activities}

For assay of SS and SPS activities the plant sample of $1 \mathrm{~g}$ from each treatment was extracted according to Hubbard et al., (1989) and assayed according to Miron and Schaffer (1991). $1 \mathrm{~g}$ plant tissue was crushed in 50 mM HEPES-NaOH buffer (pH 7.5) comprising of 1 mM EDTA, 5 mM $\mathrm{MgCl}_{2}, 0.05 \%(\mathrm{v} / \mathrm{v})$ Triton-X-100 and $2.5 \mathrm{mM}$ DTT. The homogenate was centrifuged at $10,000 \mathrm{rpm}$ for 10 mins at $4{ }^{\circ} \mathrm{C}$. For the assay of SPS activity reaction mixture was prepared using 50 mM HEPES-NaOH buffer ( $\mathrm{pH} 7.5), 15 \mathrm{mM} \mathrm{MgCl}_{2}, 25$ mM fructose-6-phosphate, 25 mM glucose-6phosphate, $25 \mathrm{mM}$ UDP-glucose and $0.1 \mathrm{ml}$ enzyme extract in a total volume of $1 \mathrm{ml}$. The reaction mix was incubated at $37^{\circ} \mathrm{C}$ for $30 \mathrm{mins}$. After incubation the reaction was stopped by adding $30 \% \mathrm{KOH}$. The composition of reaction mix to assay SS activity was same as described in SPS activity except it consisted of $25 \mathrm{mM}$ fructose instead of fructose-6-phosphate and was devoid of glucose-6-phosphate. The sucrose formed during SPS catalysed reaction and sucrose hydrolysed during SS catalysed reaction were measured by using the method by Vassey et al., (1991). The activity of SPS and SS were expressed as $\mu \mathrm{mol}$ sucrose formed/hydrolysed $\mathrm{mg}^{-1}$ protein $\mathrm{min}^{-1}$ respectively.

\subsubsection{Acid invertase (Al; EC 3.2.1.26) activity}

Acid invertase activity was measured according to Borkowska and Szczerba (1991). Plant sample of $1 \mathrm{~g}$ obtained from each treatment was crushed in $5 \mathrm{ml} 10 \mathrm{mM}$ sodium acetate buffer ( $\mathrm{pH}$ 4.6) containing $3.3 \mathrm{mM} \mathrm{MgCl}, 1 \mathrm{mM}$ EDTA and 1 mM PMSF (phenylmethylsulfonyl fluoride), centrifuged at $10,000 \mathrm{rpm}$ for 20 mins at $4^{\circ} \mathrm{C}$. The composition of the reaction mixture was $10 \mathrm{mM}$ sodium acetate buffer (pH 4.6 ), $0.4 \mathrm{M}$ sucrose and $0.25 \mathrm{ml}$ enzyme extract to make the final volume $1 \mathrm{ml}$. The reaction mix was incubated at $30^{\circ} \mathrm{C}$ for 30 mins and the reaction was stopped by adding $0.5 \mathrm{M} \mathrm{Na}_{2} \mathrm{HPO}_{4}$. The reducing sugar produced was measured according to Nelson (1944) and Somogyi (1945). The enzyme activity was expressed as $\mu$ mole sucrose hydrolysed $\mathrm{mg}^{-1}$ protein $\mathrm{min}^{-1}$. 


\subsubsection{Starch phosphorylase (SP; EC 2.4.1.1) activity}

Starch phosphorylase activity was measured by following the method of Dubey and Singh (1999). Plant sample of $1 \mathrm{~g}$ from each treatment was homogenized in $5 \mathrm{ml} 50 \mathrm{mM}$ citrate buffer ( $\mathrm{pH}$ 6) containing $1 \mathrm{mM}$ EDTA, $5 \mathrm{mM} \beta$-mercaptoethanol and $1 \mathrm{mM}$ PMSF, centrifuged at 10,000 rpm for 20 mins at $4^{\circ} \mathrm{C}$. The composition of the reaction mixture was $50 \mathrm{mM}$ citrate buffer $(\mathrm{pH} 6), 5 \%$ soluble starch $(\mathrm{w} / \mathrm{v}), 0.1 \mathrm{mM}$ glucose-1-phosphate and $0.2 \mathrm{ml}$ enzyme extract to make the final volume $1 \mathrm{ml}$. The reaction was terminated after 10 mins by adding $5 \%$ TCA. The mixture was centrifuged and the phosphorous contents in the supernatant was estimated according to Fiske and Subbarow (1925). The enzyme activity was expressed as $\mu$ mole of Pi liberated $\mathrm{mg}^{-1}$ protein $\mathrm{min}^{-1}$.

\subsection{Protein estimation}

The protein contents of enzyme extracts were estimated according to Lowry et al. (1951).

\subsection{Statistical analysis}

All the experimental values were means from three independent experiments, each with two replicates in each treatment and the results demonstrated as means \pm SE. Statistical analysis was performed by using SPSS software (PASW Statistics 18: Version 18.0.0.282). The correlation ( $r$ ) coefficient values were predicted by using Pearson's correlation analysis. Different treatment effects, viz., As and/or Si application, including control, were compared by testing the significance of their mean differences via Tukey's HSD (Honest Significant Difference) test. According to our experimental design $(4 \times 2$ block design) with the two factors, As and $\mathrm{Si}$, a two-way ANOVA was performed including the interaction effect; the resulting $p$ values corresponding to the test of significance for the main effects of $\mathrm{Si}$ indicate the strength of ameliorative effect of $\mathrm{Si}$ application in presence of As (lower the $\mathrm{p}$ values, higher the strength is). The same statistical analyses were also performed for As and/or Se application separately.

\section{Results}

\subsection{Influence of As $(V)$ with or without $S i$ and Se on pigment contents}

\subsubsection{Chlorophyll contents and fluorescence intensity}

The levels of chlorophyll-a, chlorophyll-b, total chlorophyll along with fluorescence intensity of chlorophylls were linearly decreased in $\mathrm{As}(\mathrm{V})$ treated rice seedlings over control. Upon Si and Se application in $\mathrm{As}(\mathrm{V})$ treated seedlings the chlorophyll contents and fluorescence intensity were increased than $\mathrm{As}(\mathrm{V})$ treatments alone. Under $25 \mu \mathrm{M}, 50 \mu \mathrm{M}$ and $75 \mu \mathrm{M} \mathrm{As}(\mathrm{V})$ treatments, chlorophyll contents were decreased viz., chlorophyll-a by about $24 \%, 30 \%, 42 \%$; chlorophyll-b by about $50 \%, 53 \%, 73 \%$; total chlorophyll by about $38 \%, 42 \%, 59 \%$; and fluorescence intensity of chlorophyll was also decreased by about $13 \%, 31 \%, 51 \%$, respectively, over control [Table 1]. During co-application of As(V) and Si, chlorophyll-a contents decreased by about $11 \%, 15 \%, 19 \%$; chlorophyll-b contents decreased by about $29 \%, 31 \%, 39 \%$; total chlorophyll contents reduced by about $21 \%$, $24 \%, 30 \%$; the fluorescence intensity of chlorophyll decreased by about only $2 \%, 10 \%$ and $16 \%$ respectively, over control [Table 1]. Se supplementation in $A s(V)$ treated seedlings also reduced the chlorophyll contents along with the fluorescence intensity but less than $A s(V)$ treatments alone and improvement was less than $\mathrm{As}(\mathrm{V})+\mathrm{Si}$ treated seedlings. Under combined application with $\mathrm{As}(\mathrm{V})$ and $\mathrm{Se}$, chlorophyll contents decreased viz., chl-a by about $16 \%, 22 \%, 32 \%$; chl-b by about $39 \%, 43 \%, 51 \%$; total chlorophyll by about $28 \%, 33 \%, 42 \%$ and the fluorescence intensity of chlorophylls decreased by about $8 \%, 21 \%$ and $30 \%$ respectively, over control [Table 1]. The multiple comparison analysis using Tukey's HSD (honest significant difference) tests from ANOVA showed that the said effect was statistically significant in chlorophyll-a with $p$ value 0.034 and in chlorophyll-b with $\mathrm{p}$ value 0.012 under only $75 \mu \mathrm{M} \mathrm{As}(\mathrm{V})$ treatment. The reduction in total chlorophyll contents was statistically significant under $50 \mu \mathrm{M}, 75 \mu \mathrm{M}$ and $\mathrm{Se}+75 \mu \mathrm{M} \mathrm{As}(\mathrm{V})$ treatments with $\mathrm{p}$ values $0.028,0.001$ and 0.029 respectively. The consequence of fluorescence intensity was significant under $50 \mu \mathrm{M}, 75 \mu \mathrm{M} \mathrm{As}(\mathrm{V})$ and $\mathrm{Se}+75 \mu \mathrm{M} \mathrm{As}(\mathrm{V})$ treatments with $p=0.006, p<0.001$ and $p=0.007$ respectively.

\subsubsection{Carotenoid contents}

The carotene and xanthophyll contents were linearly declined in $\mathrm{As}(\mathrm{V})$ treated test seedlings while upon $\mathrm{Si}$ and Se applications in $\mathrm{As}(\mathrm{V})$ treated test seedlings the said contents were increased than $\mathrm{As}(\mathrm{V})$ treatments alone. Carotene contents were decreased by about $25 \%, 32 \%$ and $59 \%$ [Table 1] whereas xanthophyll contents were decreased by about 19\%, 28\% and 52\% [Table 1] under $25 \mu \mathrm{M}, 50 \mu \mathrm{M}$ and $75 \mu \mathrm{M} \mathrm{As}(\mathrm{V})$ treatments respectively, over control. During joint application of $\mathrm{As}(\mathrm{V})$ and $\mathrm{Si}$, both carotene and xanthophyll contents were decreased but less than $\mathrm{As}(\mathrm{V})$ treatment alone that were by about $8 \%, 16 \%$ and $20 \%$ for carotene and by about $3 \%, 10 \%$ and $23 \%$ for xanthophyll respectively, over control. Se supplementation in As $(V)$ treated seedings, both carotene and xanthophyll contents were reduced but less than only As $(V)$ treatment and not less than in $\mathrm{As}(\mathrm{V})+\mathrm{Si}$ treated seedlings. Thus, under co-application of $\mathrm{As}(\mathrm{V})$ and $\mathrm{Se}$, carotene contents were reduced by about $19 \%, 24 \%$ and $31 \%$ while xanthophyll contents were reduced by about $13 \%, 17 \%$ and $35 \%$ respectively, over control. The depletion was significant in carotene under $50 \mu \mathrm{M}(p=0.006), 75$ $\mu \mathrm{M}(\mathrm{p}<0.001)$ and $\mathrm{Se}+75 \mu \mathrm{M}(\mathrm{p}=0.009) \mathrm{As}(\mathrm{V})$ treatments and in xanthophyll only under $75 \mu \mathrm{M} \mathrm{As}(\mathrm{V})$ treatments with $\mathrm{p}$ value 0.004. 


\begin{tabular}{|c|c|c|c|c|c|c|c|c|c|c|c|c|}
\hline $\begin{array}{l}\text { Xanthophyll } \\
\left(A_{450} \mathrm{~g}^{-1}\right. \\
\text { FW) }\end{array}$ & $\begin{array}{l}1.143 \\
\pm \\
0.062^{\mathrm{a}}\end{array}$ & $\begin{array}{l}1.166 \\
\pm \\
0.250^{a}\end{array}$ & $\begin{array}{l}1.160 \\
\pm \\
0.138^{b}\end{array}$ & $\begin{array}{l}0.931 \\
\pm \\
0.032^{\mathrm{ab}}\end{array}$ & $\begin{array}{l}1.11 \pm \\
0.072^{\mathrm{a}}\end{array}$ & $\begin{array}{l}0.993 \\
\pm \\
0.015^{b}\end{array}$ & $\begin{array}{l}0.827 \\
\pm \\
0.022^{a b}\end{array}$ & $\begin{array}{l}1.033 \\
\pm \\
0.041^{\mathrm{a}}\end{array}$ & $\begin{array}{l}0.946 \\
\pm \\
0.045^{\mathrm{ab}}\end{array}$ & $\begin{array}{l}0.546 \\
\pm \\
0.031^{b}\end{array}$ & $\begin{array}{l}0.880 \\
\pm \\
0.032^{c}\end{array}$ & $\begin{array}{l}0.746 \pm \\
0.015^{\mathrm{a}}\end{array}$ \\
\hline $\begin{array}{l}\text { Carotene } \\
\left(\mathrm{A}_{425} \mathrm{~g}^{-1}\right. \\
\mathrm{FW})\end{array}$ & $\begin{array}{l}2.306 \\
\pm \\
0.136^{a}\end{array}$ & $\begin{array}{l}2.391 \\
\pm \\
0.069^{a}\end{array}$ & $\begin{array}{l}2.338 \\
\pm \\
0.092^{b}\end{array}$ & $\begin{array}{l}1.727 \\
\pm \\
0.128^{\mathrm{ab}}\end{array}$ & $\begin{array}{l}2.125 \\
\pm \\
0.099^{\mathrm{ac}}\end{array}$ & $\begin{array}{l}1.874 \\
\pm \\
0.073^{b}\end{array}$ & $\begin{array}{l}1.560 \\
\pm \\
0.211^{\mathrm{b}}\end{array}$ & $\begin{array}{l}1.938 \\
\pm \\
0.072^{\mathrm{ac}}\end{array}$ & $\begin{array}{l}1.764 \\
\pm \\
0.129^{\mathrm{ac}}\end{array}$ & $\begin{array}{l}0.956 \\
\pm \\
0.050^{b}\end{array}$ & $\begin{array}{l}1.851 \\
\pm \\
0.123^{c}\end{array}$ & $\begin{array}{l}1.587 \pm \\
0.125^{\text {ac }}\end{array}$ \\
\hline $\begin{array}{l}\text { Fluorescence } \\
\text { Intensity } \\
\text { (arbitrary } \\
\text { units) }\end{array}$ & $\begin{array}{l}81.64 \\
\pm 2.25^{b}\end{array}$ & $\begin{array}{l}85.69 \\
\pm \\
3.24^{\mathrm{b}}\end{array}$ & $\begin{array}{l}82.49 \\
\pm \\
4.32^{\mathrm{b}}\end{array}$ & $\begin{array}{l}71.43 \\
\pm 5.96^{\mathrm{a}}\end{array}$ & $\begin{array}{l}80.34 \\
\pm \\
1.47 \mathrm{bc}\end{array}$ & $\begin{array}{l}74.95 \\
\pm 1.56^{\mathrm{a}}\end{array}$ & $\begin{array}{l}56.70 \\
\pm 6.50^{\mathrm{a}}\end{array}$ & $\begin{array}{l}73.41 \\
\pm \\
4.22^{\mathrm{bc}}\end{array}$ & $\begin{array}{l}64.36 \\
\pm 1.36^{\mathrm{b}}\end{array}$ & $\begin{array}{l}40.23 \\
\pm 5.11^{\mathrm{a}}\end{array}$ & $\begin{array}{l}68.90 \\
\pm \\
3.80^{\mathrm{c}}\end{array}$ & $\begin{array}{l}57.25 \pm \\
1.74^{c}\end{array}$ \\
\hline $\begin{array}{l}\text { Total } \\
\text { chlorophyll } \\
\left.\mathrm{mg} \mathrm{g}^{-1} \mathrm{FW}\right)\end{array}$ & $\begin{array}{l}0.199 \\
\pm \\
0.020^{\mathrm{b}}\end{array}$ & $\begin{array}{l}0.206 \\
\pm \\
0.001^{b}\end{array}$ & $\begin{array}{l}0.199 \\
\pm \\
0.003^{a}\end{array}$ & $\begin{array}{l}0.123 \\
\pm \\
0.015^{a}\end{array}$ & $\begin{array}{l}0.158 \\
\pm \\
0.016^{b}\end{array}$ & $\begin{array}{l}0.142 \\
\pm \\
0.015^{\mathrm{ac}}\end{array}$ & $\begin{array}{l}0.114 \\
\pm \\
0.016^{\mathrm{a}}\end{array}$ & $\begin{array}{l}0.152 \\
\pm \\
0.017^{d}\end{array}$ & $\begin{array}{l}0.133 \\
\pm \\
0.014^{\mathrm{ac}}\end{array}$ & $\begin{array}{l}0.082 \\
\pm \\
0.023^{\mathrm{ac}}\end{array}$ & $\begin{array}{l}0.140 \\
\pm \\
0.015^{d}\end{array}$ & $\begin{array}{l}0.115 \pm \\
0.016^{\mathrm{abc}}\end{array}$ \\
\hline $\begin{array}{l}\text { Chlorophyll-b } \\
\left(\mathrm{mg} \mathrm{g}^{-1} \mathrm{FW}\right)\end{array}$ & $\begin{array}{l}0.111 \\
\pm \\
0.014^{\mathrm{a}}\end{array}$ & $\begin{array}{l}0.116 \\
\pm \\
0.006^{\mathrm{a}}\end{array}$ & $\begin{array}{l}0.108 \\
\pm \\
0.007^{b}\end{array}$ & $\begin{array}{l}0.056 \\
\pm \\
0.016^{\mathrm{ab}}\end{array}$ & $\begin{array}{l}0.079 \\
\pm \\
0.012^{c}\end{array}$ & $\begin{array}{l}0.068 \\
\pm \\
0.013^{\mathrm{ab}}\end{array}$ & $\begin{array}{l}0.053 \\
\pm \\
0.017^{\mathrm{b}}\end{array}$ & $\begin{array}{l}0.076 \\
\pm \\
0.014^{c}\end{array}$ & $\begin{array}{l}0.064 \\
\pm \\
0.013^{b c}\end{array}$ & $\begin{array}{l}0.031 \\
\pm \\
0.018^{b}\end{array}$ & $\begin{array}{l}0.068 \\
\pm \\
0.009^{a}\end{array}$ & $\begin{array}{l}0.055 \pm \\
0.015^{c}\end{array}$ \\
\hline $\begin{array}{l}\text { Chlorophyll-a } \\
\text { (mg g g-1 FW) }\end{array}$ & $\begin{array}{l}0.089 \\
\pm \\
0.007^{\mathrm{a}}\end{array}$ & $\begin{array}{l}0.091 \\
\pm \\
0.006^{\mathrm{a}}\end{array}$ & $\begin{array}{l}0.090 \\
\pm \\
0.007^{b}\end{array}$ & $\begin{array}{l}0.068 \\
\pm \\
0.007^{\mathrm{ab}}\end{array}$ & $\begin{array}{l}0.079 \\
\pm \\
0.009^{c}\end{array}$ & $\begin{array}{l}0.074 \\
\pm \\
0.006^{\mathrm{bc}}\end{array}$ & $\begin{array}{l}0.062 \\
\pm \\
0.005^{\mathrm{ab}}\end{array}$ & $\begin{array}{l}0.075 \\
\pm \\
0.008^{\mathrm{c}}\end{array}$ & $\begin{array}{l}0.070 \\
\pm \\
0.005^{\mathrm{bc}}\end{array}$ & $\begin{array}{l}0.052 \\
\pm \\
0.008^{\mathrm{b}}\end{array}$ & $\begin{array}{l}0.072 \\
\pm \\
0.009^{d}\end{array}$ & $\begin{array}{l}0.060 \pm \\
0.090^{c}\end{array}$ \\
\hline Treatments & Control & $\begin{array}{l}2 \mathrm{mM} \\
\mathrm{Si}\end{array}$ & $\begin{array}{l}5 \mu \mathrm{M} \\
\mathrm{Se}\end{array}$ & $\begin{array}{l}25 \mu \mathrm{M} \\
\mathrm{As}(\mathrm{V})\end{array}$ & $\begin{array}{l}\mathrm{Si}+25 \\
\mu \mathrm{M} \\
\mathrm{As}(\mathrm{V})\end{array}$ & $\begin{array}{l}\mathrm{Se}+25 \\
\mu \mathrm{M} \\
\mathrm{As}(\mathrm{V})\end{array}$ & $\begin{array}{l}50 \mu \mathrm{M} \\
\mathrm{As}(\mathrm{V})\end{array}$ & $\begin{array}{l}\mathrm{Si}+50 \\
\mu \mathrm{M} \\
\mathrm{As}(\mathrm{V})\end{array}$ & $\begin{array}{l}\mathrm{Se}+50 \\
\mu \mathrm{M} \\
\mathrm{As}(\mathrm{V})\end{array}$ & $\begin{array}{l}75 \mu \mathrm{M} \\
\mathrm{As}(\mathrm{V})\end{array}$ & $\begin{array}{l}\mathrm{Si}+75 \\
\mu \mathrm{M} \\
\mathrm{As}(\mathrm{V})\end{array}$ & $\begin{array}{l}\mathrm{Se}+75 \\
\mu \mathrm{M} \\
\mathrm{As}(\mathrm{V})\end{array}$ \\
\hline
\end{tabular}

\subsection{Influence of As $(V)$ with or without Si and Se on Hill activity}

Hill activity was reduced in response to $\mathrm{As}(\mathrm{V})$ treatments in the test seedlings. The rates of reduction in the said activity were about $38 \%, 43 \%$ and $59 \%$ under $25 \mu \mathrm{M}, 50 \mu \mathrm{M}$ and $75 \mu \mathrm{M} \mathrm{As}(\mathrm{V})$ treatments respectively, over control whereas under co-application of $\mathrm{Si}+\mathrm{As}(\mathrm{V})$, said reduction was altered and much less decrease in Hill activity was recorded that were only $3 \%, 7 \%$ and $11 \%$ respectively, over control. Se supplementation in As(V) treated seedlings also reduced the said activity but more than $\mathrm{As}(\mathrm{V})+\mathrm{Si}$ treatments. During joint application of Se and $\mathrm{As}(\mathrm{V})$, Hill activity was decreased by about $8 \%, 18 \%$ and $31 \%$ respectively, over control. The said effect was statistically significant under $50 \mu \mathrm{M}$ and $75 \mu \mathrm{M} \mathrm{As}(\mathrm{V})$ treatments with $p$ values 0.047 and 0.016 respectively in the seedlings of the test cultivar [Fig. 1(a)].

\subsection{Influence of $A s(V)$ with or without $S i$ and Se on photosynthetic parameters}

\subsubsection{Internal $\mathrm{CO}_{2}$ concentration}

Internal $\mathrm{CO}_{2}$ concentration was adversely affected under $\mathrm{As}(\mathrm{V})$ stress and decreased by about $48 \%, 50 \%$ and $59 \%$ in $25 \mu \mathrm{M}, 50 \mu \mathrm{M}$ and $75 \mu \mathrm{M}$ $\mathrm{As}(\mathrm{V})$ treatments respectively, over control. In case of $\mathrm{As}(\mathrm{V})+\mathrm{Si}$ and $\mathrm{As}(\mathrm{V})+$ Se treatments, the said level was increased than $\mathrm{As}(\mathrm{V})$ treatments alone that were clearly observed with less reduction over control [Fig. 1(b)]. The said concentration was reduced under $\mathrm{As}(\mathrm{V})+\mathrm{Si}$ treatment, by about $16 \%, 24 \%$ and $27 \%$ respectively, over control. Se supplementation in $\mathrm{As}(\mathrm{V})$ treated rice seedlings reduced the said concentration but more than $\mathrm{As}(\mathrm{V})+\mathrm{Si}$ treated seedlings that were by about $21 \%, 30 \%$ and $38 \%$ respectively, over control. Tukey's HSD multiple comparisons analysis showed that the rate of reduction was significant under $25 \mu \mathrm{M}(p=0.043), 50 \mu \mathrm{M}(p=0.026)$ and $75 \mu \mathrm{M}(p=0.006) \operatorname{As}(\mathrm{V})$ treatments in the test cultivar.

\subsubsection{Net photosynthesis}

Net photosynthesis rate was also hampered in the test seedlings under $\mathrm{As}(\mathrm{V})$ stress. It was linearly decreased by about $43 \%, 54 \%$ and $66 \%$ in 25 $\mu \mathrm{M}, 50 \mu \mathrm{M}$ and $75 \mu \mathrm{M} \mathrm{As}(\mathrm{V})$ treatments respectively, over control. During joint application with Si and $\mathrm{As}(\mathrm{V})$, decrease in net photosynthesis was less than $\mathrm{As}(\mathrm{V})$ treatment alone that were by about $5 \%, 10 \%$ and $21 \%$ respectively, over control. When Se was applied in $\mathrm{As}(\mathrm{V})$ treated test seedlings, the net photosynthesis rate was also reduced but more than $\mathrm{As}(\mathrm{V})+\mathrm{Si}$ treated seedlings that were by about $16 \%, 30 \%$ and $36 \%$ respectively, over control [Fig. 1(c)]. The rate of reduction was statistically significant only under $75 \mu \mathrm{M} \mathrm{As}(\mathrm{V})$ treatment with $p$ value 0.025 .

\subsubsection{Transpiration rate}

Transpiration rate of the test seedlings decreased by $\mathrm{As}(\mathrm{V})$ application. The rates of reduction were about $24 \%, 33 \%$ and $50 \%$ in $25 \mu \mathrm{M}, 50 \mu \mathrm{M}$ and $75 \mu \mathrm{M} \mathrm{As}(\mathrm{V})$ treatments respectively, over control. During joint application with Si and $\mathrm{As}(\mathrm{V})$, rate of transpiration were reduced less than As $(\mathrm{V})$ treatments alone that were by about $7 \%, 14 \%$ and $23 \%$ respectively, over control. During co-application with $\mathrm{As}(\mathrm{V})$ and Se, the transpiration rate was reduced more than $\mathrm{As}(\mathrm{V})+\mathrm{Si}$ treatment but less than only $\mathrm{As}(\mathrm{V})$ treated seedlings that were by about $14 \%, 26 \%$ and $32 \%$ respectively, over control [Fig. 1(d)]. The effect was highly significant under $75 \mu \mathrm{M} \mathrm{As}(\mathrm{V})$ treatment with $p$ value 0.007 .

\subsubsection{Stomatal conductance}


The stomatal conductance was decreased by about $21 \%, 40 \%$ and $52 \%$ in $25 \mu \mathrm{M}, 50 \mu \mathrm{M}$ and $75 \mu \mathrm{M}$ As(V) treated seedlings respectively, over control. During joint application with $\mathrm{Si}$ and $\mathrm{As}(\mathrm{V})$, the rate of stomatal conductance was increased than $\mathrm{As}(\mathrm{V})$ treatments alone that were by about $3 \%, 12 \%$ and $21 \%$ respectively, over control. During joint application with Se and $\mathrm{As}(\mathrm{V})$, the stomatal conductance was decreased than As(V)+Si treatment but less than only $\mathrm{As}(\mathrm{V})$ treatments that were by about $13 \%, 21 \%$ and $33 \%$ respectively, over control [Fig. 1(e)]. The effect was statistically significant under $75 \mu \mathrm{M} \mathrm{As}(\mathrm{V})$ treatment with $\mathrm{p}$ value 0.017 .

\subsection{Influence of As $(V)$ with or without Si and Se on reducing, non-reducing and total soluble sugar contents 3.4.1. Reducing sugar}

Reducing sugar contents was increased in both root and shoot of the test seedlings. In root, the said contents was increased by about $68 \%, 86 \%$ and $93 \%$ while in shoot it was increased by about $70 \%, 92 \%$ and $99 \%$ under $25 \mu \mathrm{M}, 50 \mu \mathrm{M}$ and $75 \mu \mathrm{M}$ As(V) treatments respectively, over control. The reducing sugar contents was increased more in shoot than root. During joint application with Si and As(V), the said contents was increased less than $\mathrm{As}(\mathrm{V})$ treatments alone that were by about $10 \%, 28 \%, 40 \%$ in root and $15 \%, 29 \%$ and $43 \%$ in shoot under Si and said concentrations of $\mathrm{As}(\mathrm{V})$ treatments respectively, over control [Table 2]. Se supplementation in $\mathrm{As}(\mathrm{V})$ treated test seedlings enhanced the reducing sugar contents by about $40 \%, 61 \%, 71 \%$ in root and $41 \%, 63 \%, 77 \%$ in shoot respectively, over control [Table 2 ]. The increments were significant under $25 \mu \mathrm{M}(\mathrm{p}=$ 0.031 in root and 0.008 in shoot), $50 \mu \mathrm{M}(\mathrm{p}=0.003$ in root and $<0.001$ in shoot), $75 \mu \mathrm{M}(\mathrm{p}=0.001$ in root and $<0.001$ in shoot), Se $+50 \mu \mathrm{M}(\mathrm{p}=$ 0.021 in shoot) and $\mathrm{Se}+75 \mu \mathrm{M}(\mathrm{p}=0.022$ in root and 0.003 in shoot) As(V) treatments in the test cultivar.

\subsubsection{Non-reducing sugar}

Non-reducing sugar contents was also increased in both root and shoot of the test seedlings. In root, non-reducing sugar contents was increased by about $36 \%, 50 \%$ and $73 \%$ while in shoot it was increased by about $49 \%, 75 \%$ and $85 \%$ under $25 \mu \mathrm{M}, 50 \mu \mathrm{M}$ and $75 \mu \mathrm{M} \mathrm{As}(\mathrm{V})$ treatments respectively, over control. During joint application with $\mathrm{Si}$ and $\mathrm{As}(\mathrm{V})$, the said contents was increased less than $\mathrm{As}(\mathrm{V})$ treatments alone. The rate of increments was by about $9 \%, 14 \%, 22 \%$ in root and $17 \%, 24 \%$ and $33 \%$ in shoot under Si and said concentrations of As(V) treatments respectively, over control [Table 2]. During joint application with $\mathrm{As}(\mathrm{V})$ and Se, the said contents were also increased less than $\mathrm{As}(\mathrm{V})$ treatments alone but increased more than $\mathrm{Si}+\mathrm{As}(\mathrm{V})$ treatments, that were by about $22 \%, 27 \%, 42 \%$ in root and $31 \%, 43 \%$ and $52 \%$ in shoot respectively, over control [Table 2]. The effect was significant under $50 \mu \mathrm{M}(\mathrm{p}=0.009$ in root), $75 \mu \mathrm{M}(\mathrm{p}<0.001$ in root and $\mathrm{p}=0.029$ in shoot) and Se $+75 \mu \mathrm{M}$ ( $\mathrm{p}=0.048$ in root) $\mathrm{As}(\mathrm{V})$ treatments in the test cultivar.

\subsubsection{Total soluble sugar}

Total soluble sugar contents was enhanced in both root and shoot under As(V) treatments. In root, said contents were increased by about $39 \%$, $54 \%$ and $75 \%$ while in shoot it was increased by about $51 \%, 77 \%$ and $86 \%$ under $25 \mu \mathrm{M}, 50 \mu \mathrm{M}$ and $75 \mu \mathrm{M}$ As(V) treatments respectively, over control. During joint application with $\mathrm{Si}$ and $\mathrm{As}(\mathrm{V})$, the total sugar contents was increased less than $\mathrm{As}(\mathrm{V})$ treatments alone. The rates of increments were by about $9 \%, 15 \%, 24 \%$ in root and $17 \%, 24 \% 34 \%$ in shoot under Si and said concentrations of As(V) treatments respectively, over control. When Se was applied in $\mathrm{As}(\mathrm{V})$ treated test seedlings, the said contents were increased more than $\mathrm{Si}+\mathrm{As}(\mathrm{V})$ treatments but increased less than $\mathrm{As}(\mathrm{V})$ treatments alone that were by about $24 \%, 30 \%, 45 \%$ in root and $32 \%, 45 \% 54 \%$ in shoot respectively, over control. The effect was significant under $25 \mu \mathrm{M}(\mathrm{p}=0.036$ in root), $50 \mu \mathrm{M}(\mathrm{p}=0.001$ in root and 0.036 in shoot), $75 \mu \mathrm{M}(\mathrm{p}<0.001$ in root and 0.013 in shoot $)$ and Se $+75 \mu \mathrm{M}(\mathrm{p}=0.010$ in root) $\mathrm{As}(\mathrm{V})$ treatments in the test cultivar.

\subsection{Influence of $\mathrm{As}(\mathrm{V})$ with or without $\mathrm{Si}$ and Se on starch contents}

Starch contents was decreased in both root and shoot of the test seedlings under As(V) stress. Starch contents was decreased by about $46 \%$, $52 \%$ and $62 \%$ in root and by about $55 \%, 60 \%$ and $69 \%$ in shoot under $25 \mu \mathrm{M}, 50 \mu \mathrm{M}$ and $75 \mu \mathrm{M} \mathrm{As}(\mathrm{V})$ treatments respectively, over control. During joint application with Si and $\mathrm{As}(\mathrm{V})$, the starch contents was decreased less than $\mathrm{As}(\mathrm{V})$ treatments alone and rate of reductions were by about $4 \%, 12 \%$, $21 \%$ in root and $25 \%, 29 \%, 32 \%$ in shoot respectively, over control [Table 2]. During Se supplementation in As(V) exposed test seedlings, the said levels were decreased by about $19 \%, 28 \%, 33 \%$ in root and $39 \%, 42 \%, 46 \%$ in shoot respectively, over control [Table 2]. The effect was significant under $25 \mu \mathrm{M}(\mathrm{p}=0.001$ in shoot), $50 \mu \mathrm{M}(\mathrm{p}=0.044$ in root and $<0.001$ in shoot), $75 \mu \mathrm{M}(\mathrm{p}=0.009$ in root and $<0.001$ in shoot), Se $+25 \mu \mathrm{M}$ ( $\mathrm{p}=$ 0.034 in shoot), Se $+50 \mu \mathrm{M}(\mathrm{p}=0.017$ in shoot $)$ and $\mathrm{Se}+75 \mu \mathrm{M}(\mathrm{p}=0.007$ in shoot $) \mathrm{As}(\mathrm{V})$ treatments in the test cultivar. 
Table 2

Influence of increasing concentrations of $\mathrm{As}(\mathrm{V})$ with or without Si and Se on reducing sugar, non-reducing sugar and starch contents in 3 weeks old rice seedlings. Multiple comparisons of the means \pm S.E. ( $n=6$ i.e. three experiments with two replicates each) were conducted with the Tukey-Kramer HSD test. Treatments having significantly different effects (at $5 \%$ level) are marked by different alphabets, separately for root and shoot samples.

\begin{tabular}{|c|c|c|c|c|c|c|}
\hline \multirow[t]{2}{*}{ Treatments } & \multicolumn{2}{|c|}{ Reducing sugar ( $\mathrm{mg} \mathrm{g}^{-1} \mathrm{FW}$ ) } & \multicolumn{2}{|c|}{$\begin{array}{l}\text { Non-reducing sugar } \\
\text { (mg g }{ }^{-1} \mathrm{FW} \text { ) }\end{array}$} & \multicolumn{2}{|c|}{ Starch $\left(\mathrm{mg} \mathrm{g}^{-1} \mathrm{FW}\right)$} \\
\hline & Root & Shoot & Root & Shoot & Root & Shoot \\
\hline Control & $0.52 \pm 0.04^{d}$ & $0.77 \pm 0.05^{d}$ & $4.86 \pm 0.19^{c}$ & $7.83 \pm 0.97^{b}$ & $6.34 \pm 1.06^{a}$ & $14.51 \pm 0.67^{a b}$ \\
\hline $2 \mathrm{mM} \mathrm{Si}$ & $0.56 \pm 0.05^{d}$ & $0.82 \pm 0.13^{d}$ & $4.98 \pm 0.84^{c}$ & $8.26 \pm 2.04^{a b}$ & $6.72 \pm 0.40^{\mathrm{a}}$ & $16.41 \pm 0.80^{a}$ \\
\hline $5 \mu \mathrm{M} \mathrm{Se}$ & $0.57 \pm 0.060^{b c}$ & $0.79 \pm 0.08^{c}$ & $4.97 \pm 0.41^{c}$ & $8.29 \pm 1.63^{b}$ & $6.47 \pm 0.86^{a}$ & $15.27 \pm 0.69^{a}$ \\
\hline $25 \mu \mathrm{M}$ As(V) & $0.87 \pm 0.08^{a b c}$ & $1.30 \pm 0.07^{a b c}$ & $6.60 \pm 0.19^{a b c}$ & $11.64 \pm 1.49^{\mathrm{ab}}$ & $3.44 \pm 0.20^{b c}$ & $6.49 \pm 0.43^{c d}$ \\
\hline $\mathrm{Si}+25 \mu \mathrm{M} A s(V)$ & $0.57 \pm 0.023^{c d}$ & $0.88 \pm 0.06^{d}$ & $5.29 \pm 0.18^{b c}$ & $9.16 \pm 0.71^{a b}$ & $6.11 \pm 0.70^{a}$ & $10.84 \pm 1.65^{a b c}$ \\
\hline $\mathrm{Se}+25 \mu \mathrm{M} \mathrm{As}(\mathrm{V})$ & $0.73 \pm 0.045^{\mathrm{abc}}$ & $1.08 \pm 0.12^{b c}$ & $5.94 \pm 0.26^{b c}$ & $10.25 \pm 0.10^{\mathrm{ab}}$ & $5.12 \pm 1.01^{\mathrm{abc}}$ & $8.86 \pm 0.74^{\mathrm{cd}}$ \\
\hline $50 \mu \mathrm{M} A s(\mathrm{~V})$ & $0.96 \pm 0.10^{\mathrm{ab}}$ & $1.47 \pm 0.08^{\mathrm{ab}}$ & $7.31 \pm 0.52^{\mathrm{ab}}$ & $13.71 \pm 1.43^{\mathrm{ab}}$ & $3.06 \pm 0.20^{b c}$ & $5.80 \pm 0.40^{\mathrm{cd}}$ \\
\hline $\mathrm{Si}+50 \mu \mathrm{M}$ As(V) & $0.66 \pm 0.035^{b c d}$ & $0.99 \pm 0.05^{c d}$ & $5.52 \pm 0.25^{b c}$ & $9.70 \pm 0.88^{a b}$ & $5.58 \pm 0.50^{a b}$ & $10.31 \pm 1.68^{b c}$ \\
\hline $\mathrm{Se}+50 \mu \mathrm{M} \mathrm{As}(\mathrm{V})$ & $0.83 \pm 0.08^{a b c}$ & $1.25 \pm 0.09^{a b}$ & $6.16 \pm 0.26^{b c}$ & $11.21 \pm 0.68^{\mathrm{ab}}$ & $4.58 \pm 0.43^{a b c}$ & $8.40 \pm 0.83^{d}$ \\
\hline $75 \mu \mathrm{M} A s(V)$ & $1.00 \pm 0.10^{a}$ & $1.53 \pm 0.09^{a}$ & $8.40 \pm 0.67^{a}$ & $14.47 \pm 1.38^{a}$ & $2.43 \pm 0.27^{c}$ & $4.43 \pm 0.90^{d}$ \\
\hline $\mathrm{Si}+75 \mu \mathrm{M} A s(V)$ & $0.73 \pm 0.039^{a b c d}$ & $1.09 \pm 0.09^{b c d}$ & $5.94 \pm 0.40^{b c}$ & $10.40 \pm 0.87^{a b}$ & $5.00 \pm 0.45^{a b c}$ & $9.93 \pm 1.76^{\mathrm{bcd}}$ \\
\hline $\mathrm{Se}+75 \mu \mathrm{M}$ As$(V)$ & $0.88 \pm 0.08^{a b}$ & $1.36 \pm 0.08^{a b}$ & $6.91 \pm 0.09^{a b}$ & $11.91 \pm 0.69^{\mathrm{ab}}$ & $4.23 \pm 0.71^{a b c}$ & $7.79 \pm 0.90^{a b c}$ \\
\hline
\end{tabular}

\subsection{Influence $\mathrm{As}(\mathrm{V})$ with or without Si and Se on carbohydrate metabolizing enzymes}

\subsubsection{Sucrose synthesizing enzyme}

\subsubsection{Sucrose phosphate synthase (SPS; EC 2.4.1.14) activity}

SPS activity was increased in both root and shoot under $\mathrm{As}(\mathrm{V})$ stress in rice seedlings. The enzyme activity was significantly increased under $\mathrm{As}(\mathrm{V})$ treatments alone. In root, the SPS activity was increased by about $28 \%, 53 \%$ and $76 \%$ while in shoot the said activity was increased by about $46 \%$, $66 \%$ and $92 \%$ under $25 \mu \mathrm{M}, 50 \mu \mathrm{M}$ and $75 \mu \mathrm{M} \mathrm{As}(\mathrm{V})$ treatments respectively, over control. During joint application with Si and As(V), the said activity was increased less than $\mathrm{As}(\mathrm{V})$ treatments alone. The rate of increments were about $10 \%, 13 \%$ and $16 \%$ in root and $10 \%, 21 \%$ and $31 \%$ in shoot respectively, over control. Under Se and different concentrations of $\mathrm{As}(\mathrm{V})$, the enzyme activity was increased less than As(V) treatments alone but increased more than $\mathrm{Si}+\mathrm{As}(\mathrm{V})$ treatments, that were by about $16 \%, 30 \%$ and $34 \%$ in root and $26 \%, 36 \%$ and $52 \%$ in shoot respectively, over control [Fig. 2].

\subsubsection{Sucrose hydrolyzing enzymes}

\subsubsection{Sucrose synthase (SS; EC 2.4.1.13) activity}

SS activity was decreased in both root and shoot of the test seedlings under As(V) stress. In root, the enzyme activity was decreased by about $39 \%$, $44 \%$ and $69 \%$ while in shoot it was decreased by about $42 \%, 54 \%$ and $76 \%$ under $25 \mu \mathrm{M}, 50 \mu \mathrm{M}$ and $75 \mu \mathrm{M}$ As(V) treatments respectively, over control. During joint application with Si and increasing concentrations of As(V), the enzyme activity was decreased but less than As(V) treatments alone that were by about $9 \%, 16 \%, 27 \%$ in root and $13 \%, 22 \%, 35 \%$ in shoot respectively, over control. SS activity was also decreased less than $\mathrm{As}(\mathrm{V})$ treated test seedlings that were about $14 \%, 34 \%, 37 \%$ in root and $23 \%, 27 \%, 45 \%$ in shoot under Se and different concentrations of As(V) treatments respectively, over control [Fig. 3].

\subsubsection{Acid invertase (Al; EC 3.2.1.26) activity}

Al activity was increased in both root and shoot under $\mathrm{As}(\mathrm{V})$ stress in rice seedlings. In root, the enzyme activity was increased by about $33 \%, 51 \%$ and $69 \%$ while in shoot it was increased by about $43 \%, 72 \%$ and $92 \%$ under $25 \mu \mathrm{M}, 50 \mu \mathrm{M}$ and $75 \mu \mathrm{M}$ As(V) treatments respectively, over control. During joint application with Si and $\mathrm{As}(\mathrm{V})$, the enzyme activity was increased less than $\mathrm{As}(\mathrm{V})$ treatments alone that were by about $9 \%, 15 \%, 23 \%$ in root and $10 \%, 21 \%, 30 \%$ in shoot respectively, over control. Al activity was increased more under Se supplementation in As(V) treatments as 
compared to $\mathrm{As}(\mathrm{V})+\mathrm{Si}$ treated seedlings. The rate of increments were by about $14 \%, 25 \%, 38 \%$ in root and $21 \%, 34 \%, 42 \%$ in shoot under Se and different concentrations of $\mathrm{As}(\mathrm{V})$ respectively, over control [Fig. 4].

\subsubsection{Starch hydrolyzing enzymes}

\subsubsection{Starch phosphorylase (SP; EC 2.4.1.1) activity}

SP activity was increased under As(V) treatments in both root and shoot of the test seedlings. In root, the enzyme activity was increased by about $46 \%, 60 \%$ and $73 \%$ while in shoot, it was increased by about $52 \%, 78 \%$ and $90 \%$ under $25 \mu \mathrm{M}, 50 \mu \mathrm{M}$ and $75 \mu \mathrm{M} \mathrm{As}(\mathrm{V})$ treatments respectively, over control. During joint application with both $\mathrm{Si}+\mathrm{As}(\mathrm{V})$ and $\mathrm{Se}+\mathrm{As}(\mathrm{V})$, the said activity was increased less than As(V) treatments alone but the enzyme activity was increased more in $\mathrm{Se}+\mathrm{As}(\mathrm{V})$ treatments than $\mathrm{Si}+\mathrm{As}(\mathrm{V})$ treated seedlings. The rate of increments were about $14 \%, 21 \%, 27 \%$ in root and $23 \%, 28 \%$ and $35 \%$ in shoot under Si and different concentrations of As(V) treatments respectively, over control. The enzyme activity was also increased less than only $\mathrm{As}(\mathrm{V})$ treatments that were about $27 \%, 36 \%, 45 \%$ in root and $29 \%, 48 \%$ and $57 \%$ in shoot under $\mathrm{Se}+\mathrm{As}(\mathrm{V})$ treatments respectively, over control in the test cultivar [Fig. 5].

\subsection{Interrelations between the experimental factors}

The Pearson correlations between different experimental factors, in presence of $\mathrm{As}(\mathrm{V})$ and/or Si and Se, are presented in Fig. 6 as a heatmap; see Table $\mathbf{S} 1$ in the supplementary file for the correlation values along with $\mathrm{p}$ values for their significance. A strong positive correlation was observed among chlorophyll contents, carotenoid contents, Hill activity and all the photosynthetic parameters. In the present study, chlorophyll-a $(r=0.893)$, chlorophyll-b $(r=0.605)$ and total chlorophyll $(r=0.764)$ were positively correlated with internal $\mathrm{CO}_{2}$ concentration and correlation was significant at $p<0.001$ in all cases. Fluorescence intensity was also positively correlated with total chlorophyll contents $(r=0.700, p<0.001)$. The latter one was positively correlated with net photosynthesis rate at the significance level $p=0.005$. The rate of photosynthesis showed high positive correlation with transpiration rate $(r=0.813, p<0.001)$ and stomatal conductance $(p=0.806, p<0.001)$; the latter two were also highly correlated among themselves $(r=0.963)$ with $p<0.001$.

There were a highly positive correlation of total soluble sugar with reducing $(r=0.910, p<0.001)$ and non-reducing sugar $(r=0.999$, $p<0.001)$ contents. But starch contents was negatively correlated with reducing sugar $(r=-0.814, p<0.001)$, non-reducing sugar $(r=-0.812, p<0.001)$ and total soluble sugar contents $(r=-0.821, p<0.001)$. Beside these, sucrose phosphate synthase (SPS) activity was positively correlated with nonreducing sugar with the correlation being significant at $p=0.019$. But sucrose synthase (SS) activity was negatively correlated with non-reducing sugar contents $(r=-0.500, p=0.002)$. A negative correlation was also occurred between starch contents and starch phosphorylase activity $(r=$ $-0.613, p<0.001)$.

\subsection{Comparison of Si and Se based treatment effects}

For Si supplementation in As(V) treated rice seedlings, the significance of corresponding treatments effects on individual parameters were obtained by performing two-way ANOVA as per our experimental design. The resulting p-values associated with the main effects of Si in the tests of between-subjects effects indicated the strength of the treatment effects. The same was also obtained for Se supplementation and the p-values obtained in both the cases were reported in Table 3 for root and shoot separately. These were used to compare the treatment effects of Si and Se supplementation; the results clearly showed significantly stronger effects of Si in ameliorating As(V) induced toxicity as compared to Se. In particular, the treatment effects of Se supplementation on chlorophyll-a, chlorophyll-b, total chlorophyll, fluorescence intensity of the chlorophyll, Hill activity, transpiration rate, stomatal conductance, non-reducing sugar, total soluble sugar and carbohydrate metabolizing enzymes were not at all statistically significant at $95 \%$ level, whereas the effects of Si supplementation is highly significant on all the parameters (except only for sucrose synthase, acid invertase and starch phosphorylase in shoot). 
Table 3

p-values corresponding to the test of between-subject (main) effects in the two-way ANOVA performed separately for Si and Se supplementation.

\begin{tabular}{|lllll|}
\hline Experimental parameters & \multicolumn{2}{l}{ p values for Si supplementation } & \multicolumn{2}{l|}{ p values for Se supplementation } \\
\cline { 2 - 5 } & Root & Shoot & Root & Shoot \\
\hline Chlorophyll-a & - & 0.039 & - & 0.080 \\
\hline Chlorophyll-b & - & 0.035 & - & 0.086 \\
\hline Total chlorophyll & - & 0.010 & - & 0.147 \\
\hline Fluorescence intensity & - & 0.000 & - & 0.064 \\
\hline Carotene & - & 0.000 & - & 0.012 \\
\hline Xanthophyll & - & 0.016 & - & 0.030 \\
\hline Hill activity & - & 0.007 & - & 0.067 \\
\hline Internal CO ${ }_{2}$ concentration & - & 0.002 & - & 0.023 \\
\hline Net photosynthesis & - & 0.002 & - & 0.024 \\
\hline Transpiration rate & - & 0.009 & - & 0.100 \\
\hline Stomatal conductance & - & 0.003 & - & 0.068 \\
\hline Reducing sugar & 0.000 & 0.000 & 0.130 & 0.024 \\
\hline Non-reducing sugar & 0.001 & 0.013 & 0.008 & 0.098 \\
\hline Total soluble sugar & 0.000 & 0.007 & 0.003 & 0.076 \\
\hline Starch & 0.000 & 0.000 & 0.017 & 0.000 \\
\hline Sucrose phosphate synthase & 0.048 & 0.023 & 0.072 & 0.099 \\
\hline Sucrose synthase & 0.039 & 0.111 & 0.060 & 0.278 \\
\hline Acid invertase & 0.022 & 0.090 & 0.089 & 0.157 \\
\hline Starch phosphorylase & 0.045 & 0.127 & 0.097 & 0.194 \\
\hline
\end{tabular}

\section{Discussion}

\subsection{Influence on chloroplast pigments, Hill activity and photosynthetic parameters}

Chlorophylls are accountable for photosynthesis by absorbing lights and transforming it into chemical energy leading to subsequent ATP formation (Zhou et al., 2018). If there is any deviation in chlorophyll levels, it directly affects the photosynthesis rate and plants growth (Zhang et al., 2011). It has already been noted in the literature that, during $\mathrm{As}(\mathrm{III})$ and $\mathrm{As}(\mathrm{V})$ accumulation in different rice cultivars, increase in the ROS production as well as deficiency in various enzymatic and non-enzymatic antioxidants activities lead to the generation of oxidative stress (Das et al., 2018; Majumder et al., 2018, 2019). Das et al., (2018) also demonstrated that accumulation of As(V) and As(III) decreased the growth and biomass contents in rice seedlings. In the present study, chlorophyll-a, chlorophyll-b, total chlorophyll contents along with fluorescence intensity i.e. photosynthetic energy conversion indicator, carotenoids content viz., carotene and xanthophyll, Hill activity in terms of photolysis of water and all photosynthetic parameters viz., internal $\mathrm{CO}_{2}$ concentration, net photosynthesis, transpiration rate and stomatal conductance were significantly decreased under all concentrations of $\mathrm{As}(\mathrm{V})$ in the rice seedlings [Table 1]. The reductions in said parameters were due to the generation of ROS under $\mathrm{As}(\mathrm{V})$ stress that disrupts all kinds of physiological, biochemical and metabolic activities in plant cells. Chlorophyll contents was also decreased under Cu stress in bamboo (Jiang et al., 2013). This reduction in pigment contents occurs mainly by the reduced synthesis of PBG (porphobilinogen), an intermediate compound for chlorophyll biosynthesis (Cenkci et al., 2010). According to Padmaja et al., (1990), the reduction in chloroplast pigments during As toxicity apparently obstructed the $₫$-aminoevulinic acid dehydratase activity and protochlorophyllide reductase activity which induce the chlorophyll formation in plant cell. As stress decreased the chlorophyll fluorescence, efficiency of photosynthesis in lettuce (Gusman et al., 2013) and potentiality of photosystem-II in Spartina densiflora (Mateos-Naranjo et al., 2012). According to Dresler et al., (2014), the depletion in total chlorophyll contents along with the enhancement in chlorophyll a/b ratio was the results of enzyme inactivation required for the synthesis of chlorophyll pigments under $\mathrm{Cd}$ and $\mathrm{Cu}$ stresses in Zea mays seedlings which is in accordance with our study where chlorophyll a/b ratio was enhanced under As stress in rice seedlings [Table 1, 4]. During the applications of $\mathrm{As}(\mathrm{V})+\mathrm{Si}$ and $\mathrm{As}(\mathrm{V})+\mathrm{Se}$, the 
chlorophyll a/b ratios were decreased indicating the diminution of stress in the test seedlings. Similar fact was also observed in Oscimum basilicum under $\mathrm{Cu}, \mathrm{Ni}$ and $\mathrm{Zn}$ stresses where chlorophyll levels were reduced triggering low quantum yield (Georgiadou et al., 2018).

Table 4

Influence of $\mathrm{As}(\mathrm{V})$ with or without $\mathrm{Si}$ or Se on chlorophyll a/b ratio

\begin{tabular}{|llllll|}
\hline Treatments & Chlorophyll $\mathrm{a} / \mathrm{b}$ ratio & Treatments & Chlorophyll a/b ratio & Treatments & Chlorophyll a/b ratio \\
\hline Control & 0.799 & $2 \mathrm{mM} \mathrm{Si}$ & 0.785 & $5 \mu \mathrm{M} \mathrm{Se}$ & 0.833 \\
\hline $25 \mu \mathrm{M} \mathrm{As}(\mathrm{V})$ & 1.213 & $\mathrm{Si}+25 \mu \mathrm{M} \mathrm{As}(\mathrm{V})$ & 1.000 & $\mathrm{Se}+25 \mu \mathrm{M} \mathrm{As}(\mathrm{V})$ & 1.096 \\
\hline $50 \mu \mathrm{M} \mathrm{As}(\mathrm{V})$ & 1.179 & $\mathrm{Si}+50 \mu \mathrm{M} \mathrm{As}(\mathrm{V})$ & 0.989 & $\mathrm{Se}+50 \mu \mathrm{M} \mathrm{As}(\mathrm{V})$ & 1.098 \\
\hline $75 \mu \mathrm{M} \mathrm{As}(\mathrm{V})$ & 1.691 & $\mathrm{Si}+75 \mu \mathrm{M} \mathrm{As}(\mathrm{V})$ & 1.064 & $\mathrm{Se}+75 \mu \mathrm{M} \mathrm{As}(\mathrm{V})$ & 1.107 \\
\hline
\end{tabular}

Carotenoids are the non-enzymatic antioxidant that provide defense towards chlorophylls against oxidative damage (Kenneth et al., 2000; Hou et al., 2007; Sharma et al., 2012). In our study, carotenoid levels was reduced under As(V) stress in rice seedlings [Table 1]. This observation was supported by Rastgoo and Alemzadeh, (2011) in Aeluropus littoralis under Ag, Cd, Co and Pb stresses. In the study of Zhou et al., (2018), it was also reported that carotenoid levels was reduced in Acorus calamus during Sb stress. They reported that there is a positive correlation between the reduction of carotenoid levels and the less activity of photosystem-Il due to lack of electron transfer under stressed condition.

Hill activity i.e. photolysis of water was also decreased under $\mathrm{As}(\mathrm{V})$ stress. Both $\mathrm{Si}$ and Se administrations increased the said activity as compared to $\mathrm{As}(\mathrm{V})$ treatments alone. But $\mathrm{As}(\mathrm{V})+$ Si treatments enhanced the Hill activity more than $\mathrm{As}(\mathrm{V})+\mathrm{Se}$ treatments in the test cultivar [Fig. 1]. In the report of Yang et al., (2009), it has been demonstrated that the demotion in Hill activity affected phosphorylation, NADP ${ }^{+}$reduction and suppress the concentration of $\mathrm{CO}_{2}$ in the seedlings of Cucumis sativus under nitrate stress. According to them, the reduction in Hill activity restricted the phosphorylation of ADP, as a result assimilation of $\mathrm{CO}_{2}$ and the rate of photosynthesis were affected causing low growth in the said seedlings due to nitrate toxicity. Elevated level of Ni decreased the Hill activity in Zea mays significantly (Ghasemi et al., 2012). Allakhverdiev et al., (2000) stated that the dysfunction in electron transport chain which is accommodate by PS-II may repress the Hill activity in plants.

We have also studied the relationship among basic physiological parameters by comparing their values across all the treatment levels. We observed a strong linear relationship between chlorophyll-b and total chlorophyll so that either one can be predicted quite accurately from the other; the relation between chlorophyll-a and total chlorophyll is also linear but relatively weaker [Fig. 7(a)]. Similarly strong linear relations of stomatal conductance with net photosynthesis and transpiration rate were observed with the latter being stronger [Fig. 7(b)]. According to Deng et al., (2003), the opening of stomata mainly regulates the transpiration rate in plants. Thus, under $\mathrm{As}(\mathrm{V})$ stress, as stomatal conductance decreased i.e. opening of stomata were getting hampered due to $\mathrm{As}(\mathrm{V})$ toxicity, the transpiration rate was also decreased. Therefore, the reduction in chlorophyll-a, chlorophyll-b, chlorophyll a/b ratio, total chlorophyll, carotenoids, Hill activity and all the photosynthetic attributes due to As(V) toxicity might be connected with the less accumulation of carbon that consistently reduced both growth parameters and biomass contents in the test cultivar due to production of ROS under As(V) stress (Das et al., 2018). In plants, ROS production restricted the signaling pathways by weakening the PS-II activity that inhibited less photosynthesis rate by triggering photoinhibition (Gururani et al., 2015).

The generation of ROS in chloroplast may cause oxidative damage in both inner and outer membrane (Wang and Blumwald, 2014). In the study of Schneider et al., (2013), it was reported that the production of ROS during As stress depleted the rate of carbon accumulation in Leucaena leucocephala. In our study, the accumulation and/or activity of photosynthetic attributes reduced under As(V) stressed environment in rice seedlings [Fig. 1]. Si administration in As(V) treated rice seedlings increased the photosynthetic activities more than Se administration in As(V) treated seedlings.

Photosynthetic gas exchange and chlorophyll fluorescence were also alleviated due to copper toxicity in Avicennia germinans (Mendoza et al., 2013). The alleviation in net photosynthesis rate downregulates the Rubisco activity and thus hampers the activities of respiratory cycle enzymes under As toxicity (Farnese et al., 2017); the closing of stomatal aperture is also responsible for the reduction of photosynthetic activities (Sanglard et al., 2014). In some previous literatures, it has been documented that the optimal yield of rice mainly rely on the rate of photosynthesis which is correlated with the stomatal conductance (Ambavaram et al., 2014; Stuerz et al., 2014). In the present study, the reduction in stomatal conduction is highly correlated with the reduction in the transpiration rate that may be due to the superfluous water loss form the tissues of As(V) treated rice seedlings [Fig. 6] which is in accordance with the study of Gusman et al., (2013). They reported that in Lactuca sativa, when the rhizosphere was affected by $\mathrm{As}(\mathrm{V})$ and $\mathrm{As}(\mathrm{III})$ treatments, the capability of water consumption as well as internal $\mathrm{CO}_{2}$ level, stomatal conductance and transpiration rate were decreased. Low internal $\mathrm{CO}_{2}$ concentration was also noted in Zea mays under As and Cd stresses which is associated with the closing of stomata and less photosynthetic rate (Anjum et al., 2016).

Further, three dimensional (3D) scatter matrix was used to explore the influence of As(V), Si and Se in the array of wide dimension on different physiological attributes. 3D scatterplot in Fig. 8(a) represents a pronounced disparity in the range showing the influence on total chlorophyll in y axis, net photosynthesis rate in $x$ axis and Hill activity in z axis under As(V), with or without Si and Se, treated rice seedlings. Si treatments showed 
the effect at a higher range as compared to only $\mathrm{As}(\mathrm{V})$ treatments and $\mathrm{As}(\mathrm{V})+$ Se treatments, indicating greater ameliorative power of Si supplementation in increasing total chlorophyll contents, hill activity and, hence, elevating net photosynthesis rate in the presence of As( $V)$. Another 3D scatterplot [Fig. 8(b)] showed differential effects on total chlorophyll (y axis), internal $\mathrm{CO}_{2}$ concentration ( $\mathrm{x}$ axis) and fluorescence intensity of chlorophyll (z axis) under $\mathrm{As}(\mathrm{V})$, with or without Si and Se, treated rice seedlings, where similar trend was observed for $\mathrm{As}(\mathrm{V})+\mathrm{Si}$ and $\mathrm{As}(\mathrm{V})+\mathrm{Se}$ treatments.

Both silicon and selenium application in $\mathrm{As}(\mathrm{V})$ treated seedlings resulted an enhancement in mentioned parameters but $\mathrm{Si}$ was more potent than Se in improvement of photosynthesis machineries. Vaculík et al., (2020) reported that Si suppressed the gene expression viz., HMA2, OVP1, NRAMP5, LCT1, that act as transporters for metal uptake so that metal accumulation was reduced in plant cells. Si also reduced total As contents, As(III) contents and oxidative stress markers in rice seedlings under As(V) stress (Das et al., 2018). Etienne et al., (2020) stated that in Brassica napus, Si plays a vital role in the regulation of photosynthetic activities by transcriptomic alterations of DEGs (Differentially Expressed Genes) in shoots by exogenous application of $1.7 \mathrm{mM}$ sodium silicate. Silva et al., (2012) also demonstrated that Si application increased chlorophylls content and gas exchange parameters in two Lycopersicon esculentum cultivars that were exposed to drought. Si addition significantly increased fluorescence intensity of chlorophyll, photosynthesis rate and gas conductance in Fragaria sp. under water deficit conditions (Safoora et al., 2018). Si improves tolerance capacity by enhancing photosynthetic efficiency in plant cell wall (Ali et al., 2013). Se significantly increased chlorophyll a, chlorophyll b and carotenoids content in Lycium chinense leaves (Dong et al., 2012). In the study of Kadhim (2017), it was also reported that Se caused an increase in chlorophylls and carotenoids content of Cucumis melo and Phaseolus aureus Roxb. under Cd treatments. Under salinity stress, Se nanoparticles $(n)$ in low dose (nSe $10 \mu \mathrm{M})$ enhanced the photosynthetic efficiency by elevating the performance index, the quantum yield of PS-II and the potentiality of water-splitting complex in strawberry cv. Gaviota (Soleymanzadeh et al., 2020). Se nanoparticles in the range of 10 to $30 \mathrm{mg} \mathrm{I}^{-1}$ exhibited acute toxic effects and alleviated the growth of roots and leaves in Capsicum annuum whilst nSe in the range between 0.5 to $1 \mathrm{mg} \mathrm{I}^{-1}$ exhibited promotion in the said parameters and also regulated the expression of WRKY1 and bZIP1 transcription factors in DNA methylation techniques (Sotoodehnia-Korani et al., 2020). In the study of Neysanian et al., (2020), it was also reported that 3 mg I- 1 nSe application not only increased the growth, biomass contents and fruit development but also triggered the expression of $b Z I P$ transcription factor as well as miR172 gene regulation in tomato plants.

\subsection{Influence on carbohydrate metabolism}

The carbon fixed during photosynthesis is required for the synthesis of starch which is accumulates in chloroplast, is transferred to different plant parts to provide energy in the cells. If carbon metabolism is affected due to metal stress, it greatly hampers the nutrition worth of plants (Wahid et al., 2007). Carbohydrates produced during photosynthesis play crucial role to provide energy for cellular metabolism and also regulate osmotic potential and defending biomolecules (Muller et al., 2011). In our study, both reducing and non-reducing sugar contents were enhanced while starch contents was declined under $\mathrm{As}(\mathrm{V})$ stress in rice seedlings. In some previous literatures, it is noted that accumulation of sugars play a vital role as free radical scavenger, generated due to oxidative stress and regulate oxidative pentose phosphate pathway to actuate ROS (Van den Ende and Valluru, 2009; Hu et al., 2012; Peshev and Van den Ende, 2013). Reducing sugars control cell division while non-reducing sugars control differentiation of cell and cell maturity that favors the optimal growth by cell development (Eveland and Jackson, 2011; Sami et al., 2016). In our study, the enhancement levels in sugar levels was an effort to enhance tolerability in the rice seedlings under As(V) stressed environment by accommodating the breakdown of starch levels [Table 2]. It was also found that both reducing and non-reducing sugar contents were highly correlated with total soluble sugar contents with $r=0.910$ and 0.999 respectively and the correlation was significant at $p<0.001$ whereas the former two sugar contents were also highly correlated with each other $(r=0.888, p<0.001)$. Elevated level of sugar contents in the test cultivar restricted the net photosynthesis rate that might be the results of low expressions of genes leading to feedback inhibition during photosynthesis (Hammond and White, 2011). Enhanced level of reducing sugar was also reported in the study of Roychoudhury et al., (2012) under Cd toxicity in rice leaves to stabilize the cell membrane and to protect osmotic imbalance. Reducing sugar contents was also increased under $\mathrm{Cd}$ stressed almond to provide defensive responses (Nada et al., 2007). According to Hu et al., (2012), the activities of antioxidant enzymes were enhanced by glucose amendments in wheat seedlings.

Carbohydrates are stored as the form of starch in plant cells. But under various kinds of biotic and abiotic stressed environments, the breakdown of starch causes the deposition of soluble sugars in plant cells which can accumulate as storage form to supply carbon and to accomplish the fundamental metabolic activities required for proper growth and development of plants (Hurry et al. 1995; Stitt and Zeeman, 2012). In our study, the sugar contents was negatively correlated with the starch contents [Fig. 9(a)] where $r=-0.821$ and the correlation was significant at $p<0.001$. The breakdown of starch occurs when net photosynthesis is restricted and insufficient to maintain optimal growth under As(V) challenged condition [Fig. 1(c), Table 2]. So, it is supposed that the accumulation of carbon in plant cells and its implementation by the breakdown of starch is necessary for maintaining the growth of plants under stress environments. We have also studied the relationship among total soluble sugar, starch and internal $\mathrm{CO}_{2}$ concentration by comparing their values across all the treatment levels. A strong linear relationship was observed between starch contents and internal $\mathrm{CO}_{2}$ concentration [Fig. 9(a)] so that either one can be predicted quite accurately from the other; the relation between total soluble sugar and internal $\mathrm{CO}_{2}$ concentration is also linear but negative [Fig. 9(b)]

The synthesis of sucrose is controlled by sucrose phosphate synthase (SPS) activity governed by various kinds of environmental stresses (Krause et al., 1998). Enhancement in SPS activity in As(V) treated seedlings was correlated with the high accumulation of sucrose under As(V) treatments

Page 12/21 
which is also noted in the study of Yang et al., (2001). They reported that increased activity of SPS was closely associated with the accumulation of sucrose in rice leaves under water stress. Starch is degraded by starch phosphorylase (SP) activity which triggers the formation of glucose-1phosphate by reversible phosphorylation of a-glucans (Salisbury and Ross, 1991). In our study, sucrose synthase (SS) activity was decreased while activity of acid invertase (Al) was increased in $\mathrm{As}(\mathrm{V})$ applied rice seedlings. Acid invertase produces glucose and fructose while sucrose synthase forms UDP glucose and fructose (Rosa et al., 2009). Dubey and Singh (1999) demonstrated that the increment in acid invertase activity under metal toxicity favors the hexose formation which is required to balance osmoregulation in plant tissue. Joint application of Si with As(V) and Se with $\mathrm{As}(\mathrm{V})$ resulted a significant modulation in sugar accumulation and an elevation of starch contents but Si executes better performance than Se in the test seedlings by enhancing tolerance mechanism under stress condition. An increased level of chloroplast pigments content in plants under Si supplementation leads to high accumulation of starch which improves growth and development of plants during stressed environments (Kang et al., 2014). In the present study, a positive correlation was occurred between non-reducing sugar contents and SPS activity with $p=0.019$ but a negative correlation was observed between SPS activity and SS activity with $p<0.001$. The same concurrence was also occurred in the study of Verma et al., (2010) in Saccharum officinarum. SP activity was positively correlated with the soluble sugar contents in rice seedlings ( $r=0.544$, $p=$ $0.001)$ but negatively correlated with starch remobilization $(r=-0.613, p<0.001)$ [Fig. 6]. This phenomenon was also reported in the study of Yang et al., (2001) in rice under water stress. Thus, the activities of carbohydrate metabolizing enzymes were reversed during co-application of Si and Se with $\mathrm{As}(\mathrm{V})$ in the test seedlings with better performance with Si proving that Si was more capable than Se to sustain osmotic potential and enhance tolerability in rice seedlings during $\mathrm{As}(\mathrm{V})$ challenged environment.

\section{Conclusion}

Our study illustrated that $\mathrm{As}(\mathrm{V})$ stress greatly affected all the physiochemical attributes investigated viz., the levels of chlorophyll-a, chlorophyll-b, total chlorophyll, fluorescence intensity of chlorophyll, Hill activity, carotenoid levels and photosynthetic parameters like internal $\mathrm{CO}_{2}$ concentration, net photosynthesis, transpiration rate and stomatal conductance, leading to an adaptation by regulating carbohydrate metabolism in the tested seedlings of rice cv. MTU-1010. Si treatment along with As(V), however, promoted the said parameters more than Se supplementation in As(V) treated rice seedlings. Enhanced accumulation of As (see Supplementary Table S2) was the crucial features for the generation of ROS which was, in turn, responsible for enhancement of the oxidative stress markers; this possibly leads to reduced photosynthetic efficacy in As(V) treated rice seedlings as depicted by their less growth and biomass contents in our former studies (Das et al., 2018, 2021). Further, the contents of reducing sugar, non-reducing sugar and total soluble sugar were increased but the starch content was decreased, to maintain osmotic potential in cell cytoplasm under $\mathrm{As}(\mathrm{V})$ toxicity in rice seedlings. Activities of carbohydrate metabolizing enzymes were also interrupted that ultimately caused an ionic imbalance due to $\mathrm{As}(\mathrm{V})$ toxicity in rice seedlings. The activities of sucrose phosphate synthase, starch phosphorylase and acid invertase were enhanced whereas sucrose synthase activity was decreased to produce tolerance capacity under As(V) stress in the test seedlings. Application of Si or Se along with $\mathrm{As}(\mathrm{V})$ altered the stated effects to increase photosynthetic efficacy and pigment contents; these are again in consistence with the ameliorative effects of Si and Se observed on the growth and biomass contents of the rice seedlings under arsenic toxicity (Das et al., 2018, 2021). Thus, we infer that both Si and Se have the potentiality to reduce As(V) toxicity by reestablishing photosynthesis efficiency in the test cultivar, with Si being much more beneficial than Se to resist $\mathrm{As}(\mathrm{V})$ induced oxidative damage on chloroplast pigment levels as well as photosynthetic parameters in the test seedlings for betterment of growth in rice seedlings. Therefore, it can be suggested that the implementation of Si/Se enriched fertilizers in As polluted agricultural fields would be a cost-effective and farmer-friendly approach to restore both physiological and biochemical metabolic activities required for the normal growth and yield of rice.

\section{Declarations}

\&thical Approval: Not applicable.

+ Consent to Participate: Not applicable.

\& Conflict of interest statements: The authors would like to declare that they have no conflict of interest.

\section{Funding:}

No funding available.

\section{Author's contributions:}

SD conceived the study, analysed the experiments and experimental data statistically and wrote the manuscript. AKB provided supervision during the experimental design and gave the paper in its final shape.I

Acknowledgements: The authors are grateful to the Department of Science \& Technology (DST), Government of India for providing Dst-Inspire Fellowship (No. DST/INSPIRE Fellowship/2015/IF150003) to SD. All authors are grateful to Centre of advanced studies, Department of Botany, University of Calcutta for providing the infrastructure support. SD also acknowledge the valuable guidance of Dr. Abhik Ghosh, Assistant Professor, Interdisciplinary Statistical Research Unit, Applied Statistics Division, Indian Statistical Institute (ISI), Kolkata during immense statistical analysis in 
the manuscript. The authors are also grateful to Dr. Soumyajit Biswas and Prof. Asis Mazumdar, Regional-cum-Facilitation Centre (Eastern Region), National Medicinal Plants Board (NMPB), Ministry of AYUSH, Government of India, Jadavpur University, Kolkata, India for their help to estimate gas exchange attributes by providing the Li-COR instrument.

\section{References}

- Agathokleous E, Feng Z, Peñuelas J (2020) Chlorophyll hormesis: Are chlorophylls major components of stress biology in higher plants? Sci. Total Environ 726:138637. 10.1016/j.scitotenv.2020.138637

- Ali S, Farooq MA, Yasmeneen T, Hussain S, Arif MS, Abbas F, Bharwana SA, Zhang G (2013) The influence of silicon on barley growth, photosynthesis and ultra-structure under chromium stress. Ecotoxicol. Environ. Saf. 89:66-72. 10.1016/j.ecoenv.2012.11.015.

- Allakhverdiev SI, Sakamoto A, Nishiyama Y, Murata N (2000) Inactivation of photosystems I and II in response to osmotic stress in Synechococcus: contribution of water channels. Plant Physiol 122:1201-1208

- Ambavaram MMR, Basu S, Krishnan A, Ramegowda V, Batlang U, Rahman L, Baisakh N, Pereira A (2014) Coordinated regulation of photosynthesis in rice increases yield and tolerance to environmental stress. Nat Commun 31(5):5302

- Anjum SA, Tanveer M, Hussain S, Shahzad B, Ashraf U, Fahad S, Hassan W, Jan S, Khan I, Saleem MF, Bajwa AA, Wang L, Mahmood A, Samad RA, Tung SA (2016) Osmoregulation and antioxidant production in maize under combined cadmium and arsenic stress. Environ Sci Pollut Res 23:11864-11875

- Anjum SA, Tanveer M, Hussain S, Ashraf U, Khan I, Wang L (2017) Alteration in growth, leaf gas exchange, and photosynthetic pigments of maize plants under combined cadmium and arsenic stress. Water Air Soil Pollut 228:13

- Arnon DI (1949) Copper enzymes in isolated chloroplasts, polyphenol oxidase in Beta vulgaris. Plant Physiol 24:1-15. 10.1104/pp.24.1.1

- Bagheri A, Sadeghipour O (2009) Effects of salt stress on yield, yield components and carbohydrates content in four hullless barley (Hordeum vulgare L.) cultivars. J Biol Sci 9:909-912

- Bankaji I, Sleimi N, López-Climent MF, Perez-Clemente RM, Gomez-Cadenas A (2014) Effect of combined abiotic stresses on growth, trace element accumulation and phytohormone regulation in two halophytic species. Plant Growth Regul 33:632-643

- Biswas S, Bala S, Mazumdar A (2013) Carbon sequestration potential of agroforestry species in red and laterite zone of West Bengal towards sustainable development. Indian J Environ Prot 33(2):109-118

- Borkowska B, Szczerba J (1991) Influence of different carbon sources on invertase activity and growth of sourcherry (Prunus cerasus L.) shoot cultures. J Exp Bot 42:911-915. 10.1093/jxb/42.7.911

- Cenkci S, Cigerci IH, Yildiz M, Ozay C, Bozdag A, Terzi H (2010) Lead contamination reduces chlorophyll biosynthesis and genomic template stability in Brassica rapa L. Environ. Exp Bot 67:467-473

- Chu J, Yao X, Zhang Z (2010) Responses of wheat seedlings to exogenous selenium supply under cold stress. Biol Trace Elem Res 136:355363

- Das S, Majumder B, Biswas AK (2018) Modulation of growth, ascorbate-glutathione cycle and thiol metabolism in rice (Oryza sativa L. cv. MTU-1010) seedlings by arsenic and silicon. Ecotoxicol 27(10):1387-1403

- Das S, Majumder B, Biswas AK (2021) Selenium alleviates arsenic induced stress by modulating growth, oxidative stress, antioxidant defense and thiol metabolism in rice seedlings. Under review

- Davies BH (1965) Analysis of carotene pigments. In: Goodwin TW, (ed) Chemistry and Biochemistry of Plant Pigments. Academic Press, New York, pp 489-531

- Djanaguiraman M, Devi DD, Shanker AK, Sheeba JA, Bangarusamy U (2005) Selenium - an antioxidative protectant in soybean during senescence. Plant Soil 272:77-86

- Dong JZ, Wang Y, Wang SH, Yin LP, Xu GJ, Zheng C, Lei C, Zhang MZ (2012) Selenium increases chlorogenic acid, chlorophyll and carotenoids of Lycium chinense leaves. J Sci Food Agric 93(2):310-315. 10.1002/jsfa.5758

- Dresler S, Hanaka A, Bednarek W, Maksymiec W (2014) Accumulation of low-molecular-weight organic acids in roots and leaf segments of Zea mays plants treated with cadmium and copper. Acta Physiol Plant 36:1565-1575

- Dubey RS, Singh AK (1999) Salinity induces accumulation of soluble sugars and alters the activity of sugar metabolising enzymes in rice plants. Biol Plant 42:233-239

- Dubois M, Gilles KA, Hamilton JK, Rebers PA, Smith F (1956) Colorimetric method for determination of sugars and related substances. Anal Chem 28(3):350-356

- Drążkiewicz M, Baszyński T (2010) Interference of nickel with the photosynthetic apparatus of Zea mays. Ecotoxicol Environ Saf 73(5):982986

- Etienne P, Trouverie J, Haddad C, Arkoun M, Yvin JC, Caïus J, Brunaud V, Laîné P (2020) Root silicon treatment modulates the shoot transcriptome in Brassica napus L. and in particular upregulates genes related to ribosomes and photosynthesis. Silicon. 10.1007/s12633-

Page $14 / 21$ 


\section{0-00710-z}

- Eveland AL, Jackson DP (2011) Sugars, signalling, and plant development. J Exp Bot 63(9):3367-3377

- Farnese FS, Oliveira JA, Paiva EAS, Menezes-Silva PE, Silva AAD, Campos FV, Ribeiro C (2017) The involvement of nitric oxide in integration of plant physiological and ultrastructural adjustments in response to arsenic. Front Plant Sci 8:516

- Feng R, Wei C, Tu M, Sun X (2009) Interactive Effects of selenium and arsenic on their uptake by Pteris vittata L. under hydroponic conditions. Environ Exp Bot 65(2):363-368

- Fiske CH, Subbarow Y (1925) The colorimetric determination of phosphorus. J Biol Chem 66:375-400

- Georgiadou EC, Kowalska E, Patla K, Kulbat K, Smolińska B, Leszczyńska J, Fotopoulos V (2018) Influence of heavy metals (Ni, Cu, and Zn) on nitro-oxidative stress responses, proteome regulation and allergen production in basil (Ocimum basilicum L.) plants. Front. Plant Sci 5(9):862

- Ghasemi F, Heidari R, Jameii R, Purakbar L (2012) Effects of Ni2+ toxicity on Hill reaction and membrane functionality in maize. J. Stress Physiol. Biochem. 8(4):55-61.

- Gururani MA, Venkatesh J, Tran LSP (2015) Regulation of photosynthesis during abiotic stress-induced photoinhibition. Mol Plant 8:13041320

- Gusman GS, Oliveira JA, Farnese FS, Cambraia J (2013) Arsenate and arsenite: the toxic effects on photosynthesis and growth of lettuce plants. Acta Physiol Plant 35:1201-1209

- Hammond JP, White PJ (2011) Sugar signaling in root responses to low phosphorus availability. Plant Physiol 156:1033-1040

- Hanley ME, May OC (2005) Cotyledon damage at the seedling stage affects growth and flowering potential in mature plants. New Phytol 169(2):243-250

- Hasanuzzaman M, Fujita M (2011) Selenium pretreatment upregulates the antioxidant defense and methylglyoxal detoxification system and confers enhanced tolerance to drought stress in rapeseed seedlings. Biol Trace Elem Res 143:1758-1776

- Hoagland DR, Arnon DI (1950) The water culture method for growing plants without soil. Calif Agric Exp Sta 347:1-32

- Hou W, Chen X, Song G, Wang Q, Chang CC (2007) Effects of copper and cadmium on heavy metal polluted waterbody restoration by duckweed (Lemna minor). Plant Physiol Biochem 45:62-69

- Hu M, Shi Z, Zhang Z, Zhang Y, Li H (2012) Effects of exogenous glucose on seed germination and antioxidant capacity in wheat seedlings under salt stress. Plant Growth Regul 68:177e188

- Hubbard NL, Huber SC, Pharr DM (1989) Sucrose phosphate synthase and acid invertase as determinant of sucrose concentration in developing muskmelon (Cucumis melo L.) fruits. Plant Physiol. 91:1527-1534.

- Hurry VM, Strand A, Tobiaeson M, Gardeström P, Öquist G (1995) Cold hardening of spring and winter wheat and rape results in differential effects on growth, carbon metabolism, and carbohydrate content. Plant Physiol 109:697-706

- IARC (2004) Some drinking-water disinfectants and contaminants, including arsenic. IARC Monogr. Eval. Carcinog. Risks Hum. 84:1-477.

- Jiang L, Shi G, Ding Y, Lou L, Cai Q (2013) Differential responses of two bamboo species (Phyllostachys auresulcata 'Spectabilis' and Pleioblastus chino 'Hisauchii') to excess copper. Bioenerg Res 6:1223-1229

- Kadhim RE (2017) Effect of selenium and cadmium in chlorophylls and carotenoid content of Phaseolus aureus roxb. Pak J Biotechnol 14(4):767-770

- Kang SM, Khan AL, Waqas M, You YH, Kim JH, Kim JG, Hamayun M, Lee IJ (2014) Plant growth-promoting rhizobacteria reduce adverse effects of salinity and osmotic stress by regulating phytohormones and antioxidants in Cucumis sativus. J Plant Interact 9(1):673-682

- Kenneth E, Pallett KE, Young AJ (2000) Carotenoids. In: Ruth GA, Hess JL (eds) Antioxidants in higher plants. CRC Press, USA

- Krause KPL, Hill R, Reimholz NT, Hamborg U, Sonnewald SM (1998) Sucrose metabolism in cold-stored potato tubers with decreased expression of sucrose phosphate synthase. Plant Cell Environ 21:285-299

- Kumar M, Bijo AJ, Baghel RS, Reddy CRK, Jha B (2012) Selenium and spermine alleviates cadmium induced toxicity in the red seaweed Gracilaria dura by regulating antioxidant system and DNA methylation. Plant Physiol Biochem 51:129-138

- Lemoine R, Camera S, Atanassova R, Dedaldechamp F, Allario T, Pourtau N, Bonnemain JL, Laloi M, Coutos-Thevenot P, Maurousset L, Faucher M, Girousse Lemonnier CP, Parrilla J, Mickael D (2013) Source-to-sink transport of sugar and regulation by environmental factors. Front Plant Sci 4:1-21

- Lowry OH, Rosebrough NJ, Farr AL, Randall RJ (1951) Protein measurement with the folin phenol reagent. J Biol Chem 193:265-275

- Majumder B, Das S, Mukhopadhyay S, Biswas AK (2018) Identification of arsenic-tolerant and arsenic-sensitive rice (Oryza sativa L.) cultivars on the basis of arsenic accumulation assisted stress perception, morpho-biochemical responses, and alteration in genomic template stability. Protoplasma 256(1):193-211

- Majumder B, Das S, Pal B, Biswas AK (2019) Evaluation of arsenic induced toxicity based on arsenic accumulation, translocation and its implications on physio-chemical changes and genomic instability in indica rice (Oryza sativa L.) cultivars. Ecotoxicology. 10.1007/s10646019-02135-w 
- Mateos-Naranjo E, Andrades-moreon L, Redondo-Gomez S (2012) Tolerance to and accumulation of arsenic in the cordgrass Spartina densiflora Brongn. Bioresour Technol 104:187-194

- McCready RM, Guggolz J, Silviera V, Owens HS (1950) Determination of starch and amylase in vegetables. Anal Chem 22:1156-1158

- Mendoza DG, Gil FE, Fernando EG, Santamaría JM, Omar ZP (2013) Copper stress on photosynthesis of black mangle (Avicennia germinans). Ann Braz Acad Sci 85(2):665-670. 10.1590/S0001-37652013000200013

- Milivojevic DB, Nikolic BR, Drinic G (2006) Effect of arsenic on phosphorus content in different organs and chlorophyll fluorescence in primary leaves of soybean. Biol Plant 50:149-151

- Miller GL (1972) Use of dinitrosalicylic acid reagent for determination of reducing sugars. Anal Chem 31:426-428

- Miron D, Schaffer AA (1991) Sucrose phosphate synthase, sucrose synthase, and invertase activities in developing fruit of Lycopersicon esculentum Mill. and the sucrose accumulating Lycopersicon hirsutum Humb. and Bonpl. Plant Physiol 95:623-627

- Missana T, Alonso U, García-Gutiérrez M (2009) Experimental study and modeling of selenite sorption ontoillite and smectite clays. J Colloid Interface Sci 334:132-138

- Mitani N, Yamaji N, Ma JF (2008) Characterization of substrate specificity of a rice silicon transporter, Lsi1. Pflug Arch 456(4):679-686

- Muller B, Pantin F, Genard M, Turc O, Freixes S, Piques M, Gibon Y (2011) Water deficits uncouple growth from photosynthesis, increase C content, and modify the relationships between $\mathrm{C}$ and growth in sink organs. J Exp Bot 62:1715-1729

- Nada E, Ferjani BA, Rhouma A, Bechir BR, Imed M, Makki B (2007) Cadmium-induced growth inhibition and alteration of biochemical parameters in almond seedlings grown in solution culture. Acta Physiol Plant 29:57-62

- Naureen G, Naqvi FN (2010) Salt tolerance classification in wheat genotypes using reducing sugar accumulation and growth characteristic. Emirates J Food Agric 22:308-317

- Nelson N (1944) A photometric adaptation of the Somogyi method for the determination of glucose. J Biol Chem 153:375-380

- Neysanian M, Iranbakhsh A, Ahmadvand R, Oraghi Ardebili Z, Ebadi M (2020) Comparative efficacy of selenate and selenium nanoparticles for improving growth, productivity, fruit quality, and postharvest longevity through modifying nutrition, metabolism, and gene expression in tomato; potential benefits and risk assessment. PLoS ONE 15(12):e0244207

- Ohashi Y, Nakayama N, Saneoka H, Fujita K (2006) Effects of drought stress on photosynthetic gas exchange, chlorophyll fluorescence and stem diameter of soybean plants. Biol Plant 50:138-141

- Padmaja K, Prasad DDK, Prasad ARK (1990) Inhibition of chlorophyll synthesis in Phaseolus vulgaris seedlings by cadmium acetate. Photosynthetica 24:399-405

- Pandey C, Gupta M (2015) Selenium and auxin mitigates arsenic stress in rice (Oryza sativa L.) by combining the role of stress indicators, modulators and genotoxicity assays. J Hazard Mater 287:384-391

- Peshev D, Van den Ende W (2013) Sugars as antioxidants in plants. In: Tuteja N, Gill SS Crop Improvement under Adverse Conditions eds. Springer-Verlag, Berlin, pp 285-308

- Rastgoo L, Alemzadeh A (2011) Biochemical responses of Gouan (Aeluropus littoralis) to heavy metals stress. Aust J Crop Sci 5(4):375-383

- Rosa M, Prado C, Podazza G, Interdonato R, González JA, Hilal M, Prado FE (2009) Soluble sugars - Metabolism, sensing and abiotic stress: A complex network in the life of plants. Plant Signal Behav 4(5):388-393

- Roychoudhury A, Basu S, Sengupta DN (2012) Antioxidants and stress-related metabolites in the seedlings of two indica rice varieties exposed to cadmium chloride toxicity. Acta Physiol Plant 34:835-847

- Safoora D, Cyrus G, Bahram B, Mahdi G, Siamak S (2018) Effect of silicon on growth and development of strawberry under water deficit conditions. Hortic. Plant J 4:226-232

- Shahid MA, Balal RM, Khan N, Zotarelli L, Liu GD, Sarkhosh A, Fernández-Zapata JC, Nicolás JJM, Garcia-Sanchez F (2019) Selenium impedes cadmium and arsenic toxicity in potato by modulating carbohydrate and nitrogen metabolism. Ecotoxicol Environ Saf 180:588-599

- Salisbury FB, Ross CW (1991) Plant physiology, 4th Edition, CBS Piblishers and Distributors, New Delhi

- Sami F, Yusuf M, Faizan M, Faraz A, Hayat S (2016) Role of sugars under abiotic stress. Plant Physiol Biochem 109:54-61

- Sanglard LM, Martins SC, Detmann KC, Silva PE, Lavinsky AO, Silva MM, Detmann E, Araújo WL, DaMatta FM (2014) Silicon nutrition alleviates the negative impacts of arsenic on the photosynthetic apparatus of rice leaves: an analysis of the key limitations of photosynthesis. Physiol Plant 152(2):355-366

- Schneider J, Labory CRG, Rangel WM, Alves E, Guilherme LRG (2013) Anatomy and ultrastructure alterations of Leucaena leucocephala (Lam.) Inoculated with mycorrhizal fungi in response to arsenic-contaminated soil. J Hazard Mater 262:1245-1258

- Sharma P, Jha AB, Dubey RS, Pessarakli M (2012) Reactive oxygen species, oxidative damage, and antioxidative defense mechanism in plants under stressful conditions. J Bot 2012:217037, 26 pages

- Sil P, Das P, Biswas S, Mazumdar A, Biswas AK (2019) Modulation of photosynthetic parameters, sugar metabolism, polyamine and ion contents by silicon amendments in wheat (Triticum aestivum L.) seedlings exposed to arsenic. Environ Sci Pollut Res. 10.1007/s11356-019- 
04896-7

- Silva ON, Lobato AK, Ávila FW, Costa RC, Neto CO, Santos Filho BG, Martins Filho AP, Lemos RP, Pinho JM, Medeiros MB, Cardoso MS (2012) Silicon-induced increase in chlorophyll is modulated by the leaf water potential in two water-deficient tomato cultivars. Plant Soil Environ 58(11):481-486

- Singh N, Karambelkar A, Gu L, Lin K, Miller JS, Chen CS, Sailor MJ, Bhatia N (2011) Bioresponsive mesoporous silica nanoparticles for triggered drug release. J Am Chem Soc 133:19582-19585

- Smedley PL, Kinniburgh DG (2002) A review of the source, behaviour and distribution of arsenic in natural waters. Applied Geochem 17(5):517-568

- Soleymanzadeh R, Iranbakhsh A, Habibi G, Ardebili ZO (2020) Selenium nanoparticle protected strawberry against salt stress through modifications in salicylic acid, ion homeostasis, antioxidant machinery, and photosynthesis performance. Acta Biologica Cracoviensia Series Botanica 62(1):33-42

- Somogyi M (1945) A new reagent for the determination of sugar. J Biol Chem 60:61-68

- Sotoodehnia-Korani S, Iranbakhsh A, Ebadi M, Majd A, Ardebili ZO (2020) Selenium nanoparticles induced variations in growth, morphology, anatomy, biochemistry, gene expression, and epigenetic DNA methylation in Capsicum annuum; an in vitro study. Environmental Pollut 265:114727

- Srivastava S, Srivastava AK, Singh B, Suprasanna P, D'souza SF (2013) The effect of arsenic on pigment composition and photosynthesis in Hydrilla verticillata. Biol Plant 57(2):385-389

- Stitt M, Zeeman SC (2012) Starch turnover: pathways, regulation and role in growth. Curr Opin Plant Biol 15:282-292

- Stuerz S, Sow A, Muller B, Manneh B, Asch F (2014) Canopy microclimate and gas exchange in response to irrigation system in lowland rice in the Sahel. Field Crops Res 163:64-73

- Vaculík M, Lukačová Z, Bokor B, Martinka M, Tripathi DK, Lux A (2020) Alleviation mechanisms of metal(loid) stress in plants by silicon: A review. J Exp Bot 71(21):6744-6757

- Van den Ende W, Valluru R (2009) Sucrose, sucrosyl oligosaccharides, and oxidative stress: scavenging and salvaging? J Exp Bot 60:9-18

- Vassey TL, Quick WP, Sharkley TD, Stitt M (1991) Water stress, $\mathrm{CO}_{2}$ and light effects on sucrose phosphate synthase activity in Phaseolus vulgaris. Physiol Plant 81:37-44

- Verma AK, Upadhyay SK, Verma PC, Solomon S, Singh SB (2010) Functional analysis of sucrose phosphate synthase (SPS) and sucrose synthase (SS) in sugarcane (Saccharum) cultivars. Plant Biol 13(2):325-332

- Vishniac W (1957) Methods for the study of Hill reaction. In: Colowick SP, Kaplan NO (eds) Methods of enzymology, vol 4. Academic press, New York, pp 342-355

- Wang S, Blumwald E (2014) Stress-induced chloroplast degradation in Arabidopsis is regulated via a process independent of autophagy and senescence-associated vacuoles. Plant Cell 26:4875-4888

- Wattanapayapkul W, Polthanee A, Siri B, Bhadalung N, Promkhambut A (2011) Effects of silicon in suppressing blast disease and increasing grain yield of organic rice in Northeast Thailand. Asian J Plant Pathol 5:134-145

- Wahid A, Ghani A, Ali I, Ashraf MY (2007) Effects of cadmium on carbon and nitrogen assimilation in shoots of mungbean [Vigna radiata (L.) Wilczek] seedlings. J Agron Crop Sci 193:357-365

- WHO (2001) Arsenic and Arsenic Compounds (Environmental Health Criteria 224), 2nd edn. World Health Organization, International Programme on Chemical Safety, Geneva

- Wu Z, Bañuelos GS, Lin ZQ, Liu Y, Yuan L, Yin X, Li M (2015) Biofortification and phytoremediation of selenium in China. Front Plant Sci 6:136

- Yang J, Zhang J, Wang Z, Zhu Q (2001) Activities of starch hydrolytic enzymes and sucrose-phosphate synthase in the stems of rice subjected to water stress during grain filling. J Exp Bot 52:2169-2179. 10.1093/jexbot/52.364.2169

- Yang X, Wang X, Wei M, Hikosaka S, Goto E (2009) Changes in growth and photosynthetic capacity of cucumber seedlings in response to nitrate stress. Braz J Plant Physiol 21(4):309-317

- Zhang J, Zhang Y, Du Y, Chen S, Tang H (2011) Dynamic metabonomic responses of tobacco (Nicotiana tabacum) plants to salt stress. J Proteome Res 10(4):1904-1914

- Zhao FJ, Ma JF, Meharg AA, McGrath SP (2009) Arsenic uptake and metabolism in plants. New Phytol 181(4):777-794

- Zhou J, Zhang Z, Zhang Y, Wei Y, Jiang Z (2018) Effects of lead stress on the growth, physiology, and cellular structure of privet seedlings. PLoS One 13(3):e0191139

\section{Figures}



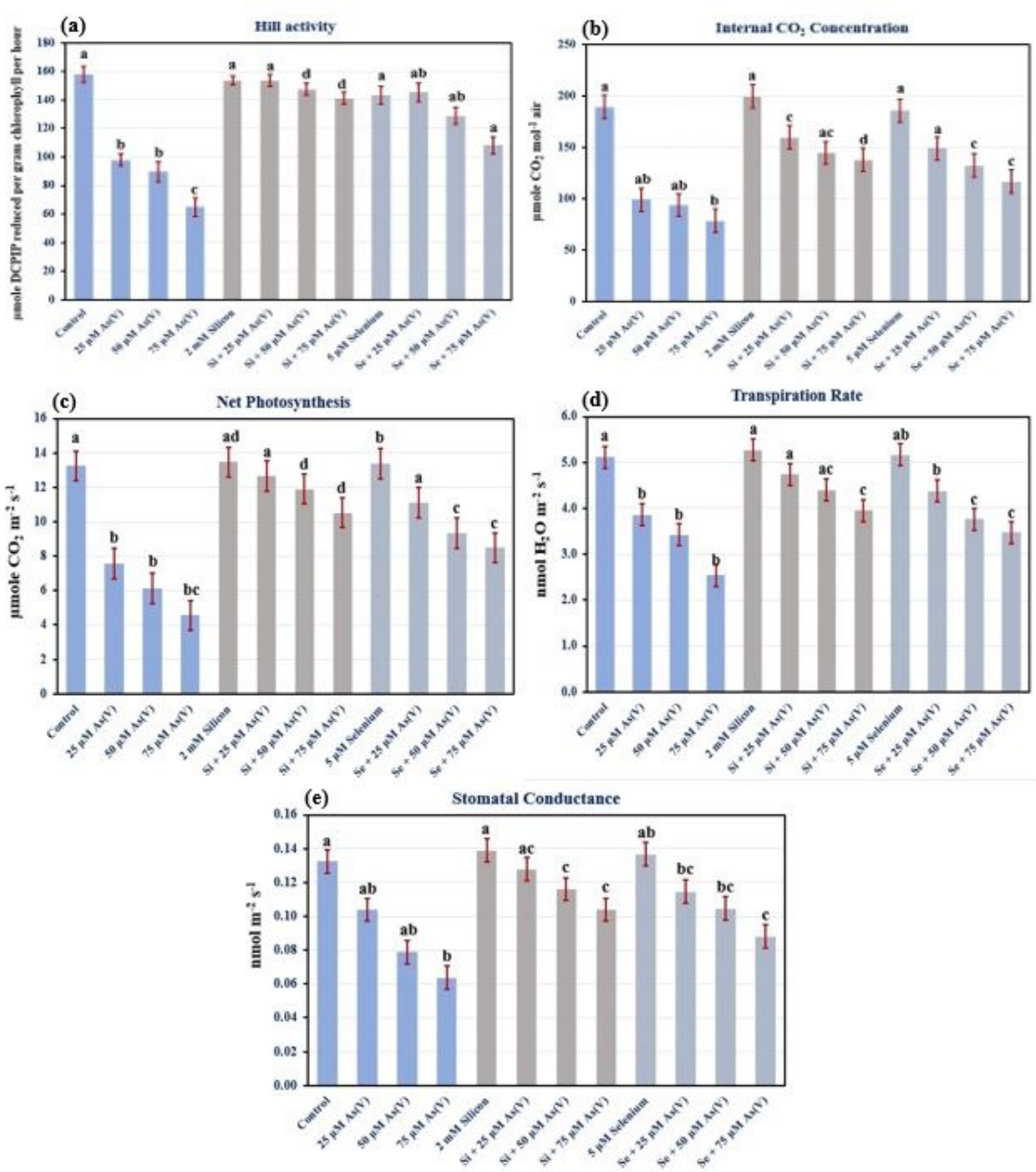

Figure 1

Influence of increasing concentrations of $\mathrm{As}(\mathrm{V})$ with or without $\mathrm{Si}$ and Se on Hill activity (a) and photosynthetic parameters viz., internal $\mathrm{CO} 2$ concentration (b), net photosynthesis (c), transpiration rate (d) and stomatal conductance (e) in 3 weeks old rice seedlings. Multiple comparisons of the means \pm S.E. ( $n=6$ i.e. three experiments with two replicates each) were conducted with the Tukey-Kramer HSD test. Treatments having significantly different effects (at $5 \%$ level) are marked by different alphabets.
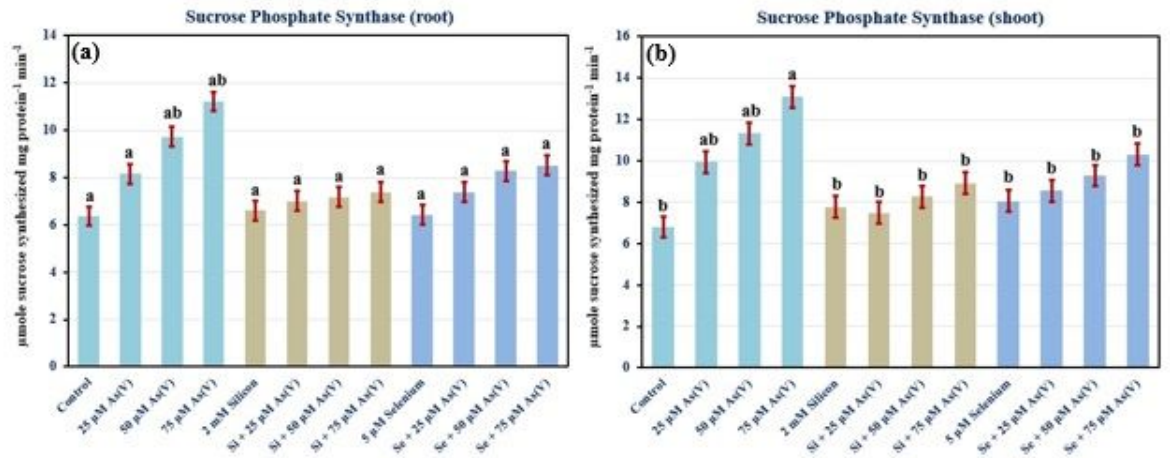

Figure 2

Influence of increasing concentrations of $\mathrm{As}(\mathrm{V})$ with or without $\mathrm{Si}$ and Se on SPS activity in 3 weeks old rice seedlings. Multiple comparisons of the means \pm S.E. ( $n=6$ i.e. three experiments with two replicates each) were conducted with the Tukey-Kramer HSD test. Treatments having significantly different effects (at $5 \%$ level) are marked by different alphabets, separately for root and shoot samples. 

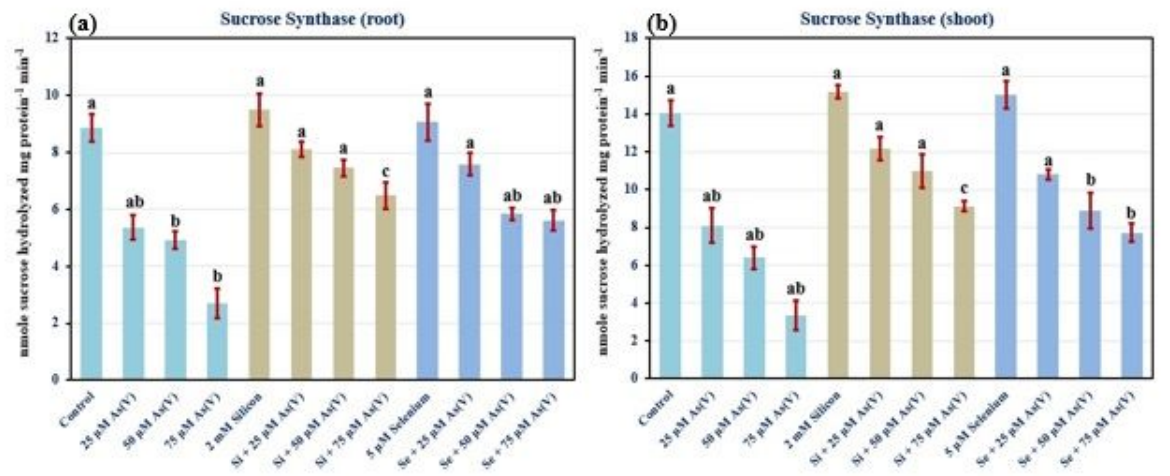

Figure 3

Influence of increasing concentrations of $\mathrm{As}(\mathrm{V})$ with or without Si and Se on SS activity in 3 weeks old rice seedlings. Multiple comparisons of the means \pm S.E. ( $n=6$ i.e. three experiments with two replicates each) were conducted with the Tukey-Kramer HSD test. Treatments having significantly different effects (at $5 \%$ level) are marked by different alphabets, separately for root and shoot samples.
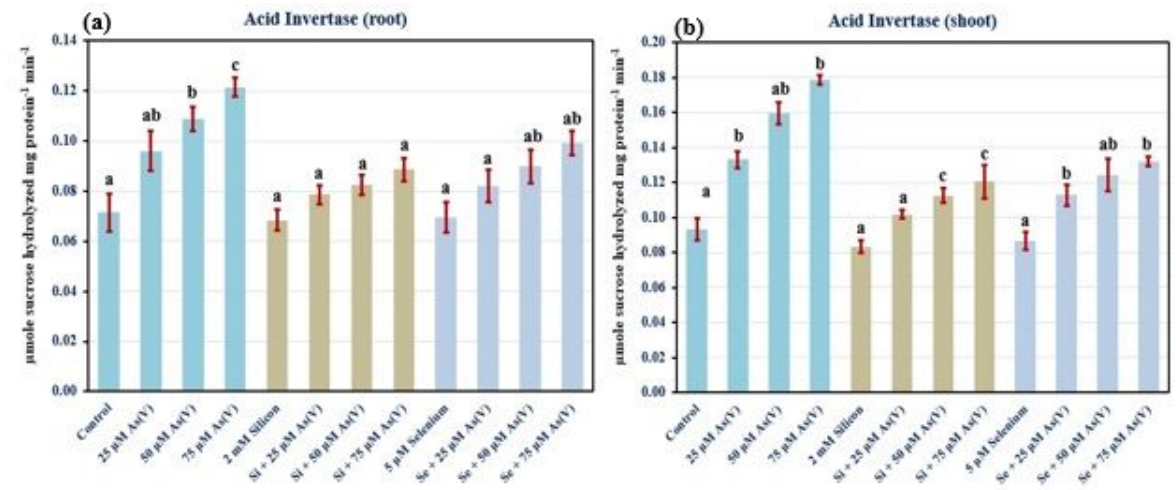

\section{Figure 4}

Influence of increasing concentrations of $\mathrm{As}(\mathrm{V})$ with or without Si and Se on Al activity in 3 weeks old rice seedlings. Multiple comparisons of the means \pm S.E. ( $n=6$ i.e. three experiments with two replicates each) were conducted with the Tukey-Kramer HSD test. Treatments having significantly different effects (at $5 \%$ level) are marked by different alphabets, separately for root and shoot samples.
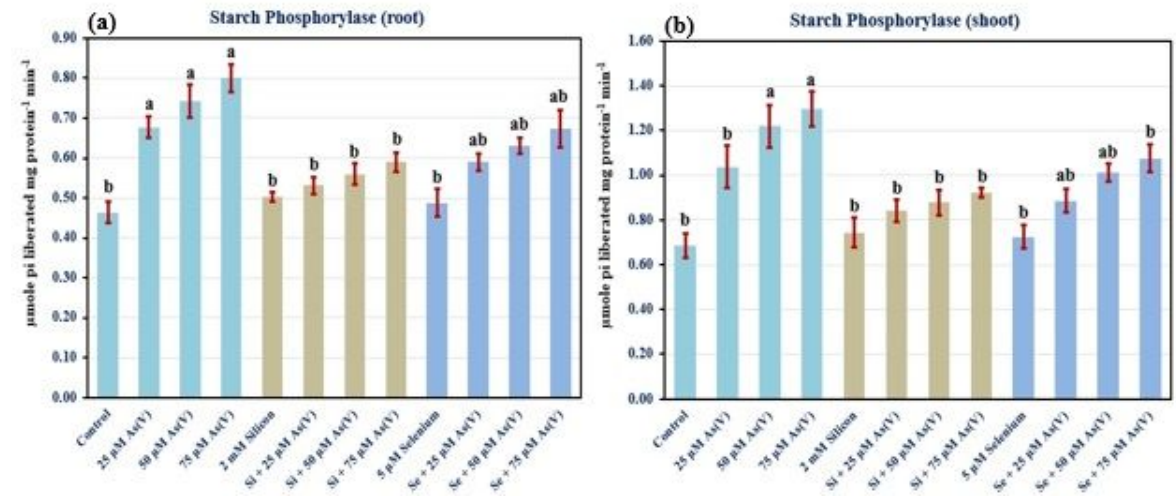

Figure 5

Influence of increasing concentrations of $\mathrm{As}(\mathrm{V})$ with or without Si and Se on SP activity in 3 weeks old rice seedlings. Multiple comparisons of the means \pm S.E. ( $n=6$ i.e. three experiments with two replicates each) were conducted with the Tukey-Kramer HSD test. Treatments having significantly different effects (at $5 \%$ level) are marked by different alphabets, separately for root and shoot samples. 


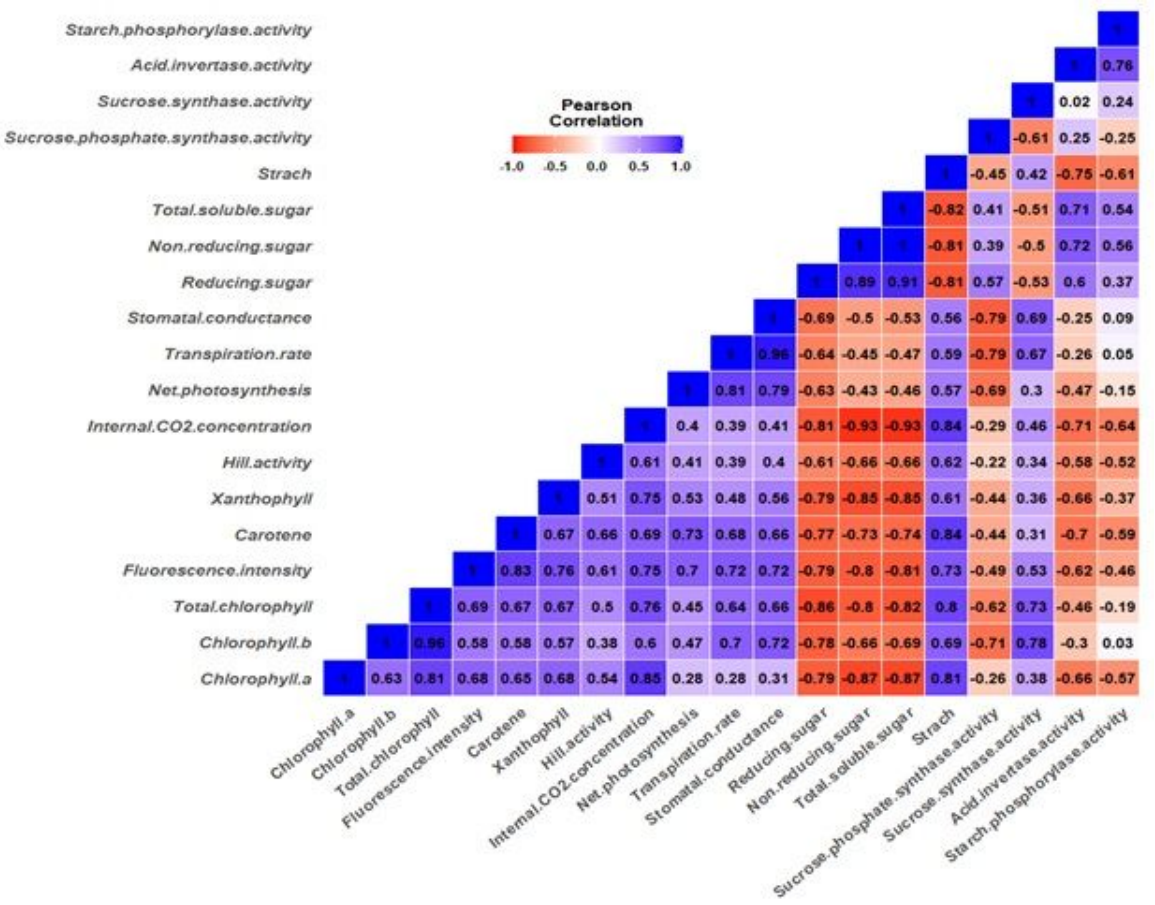

\section{Figure 6}

Heatmap of the correlations among different experimental factors.
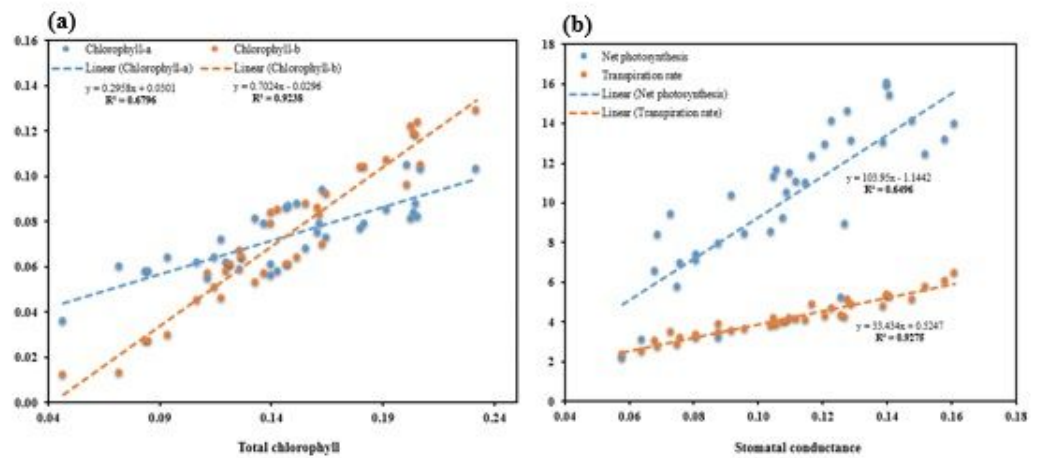

Figure 7

Plots represention the relations of (a) chlorophyll-a and chlorophyll-b with total chlorophyll, (b) net photosyntheis and transpiration rate with stomatal conductance in 3 weeks old rice seedlings.
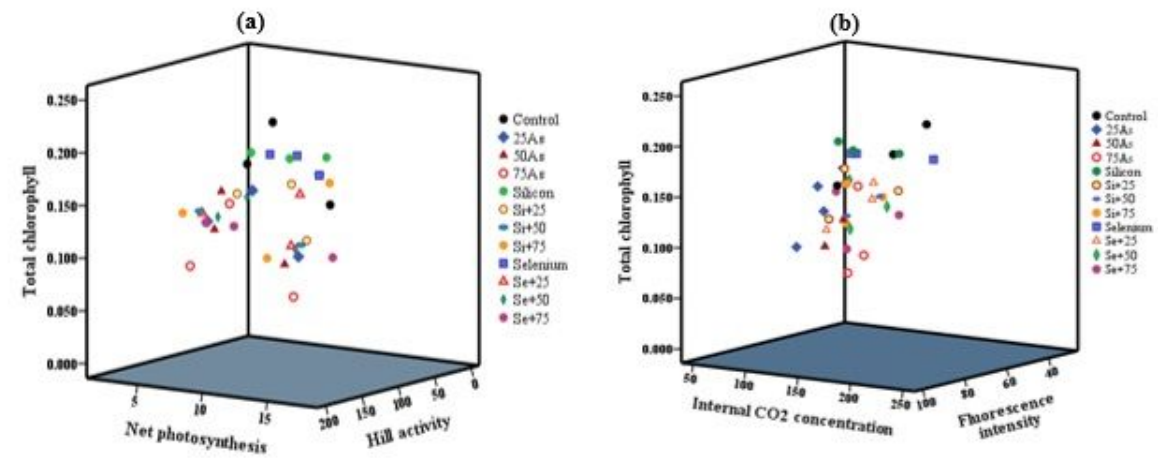

\section{Figure 8}

3D scatterplot of (a) total chlorophyll, net photosynthesis and Hill activity, and (b) total chlorophyll, internal CO2 concentration and fluorescence intensity of chlorophyll under different treatment levels in 3 weeks old rice seedlings. 

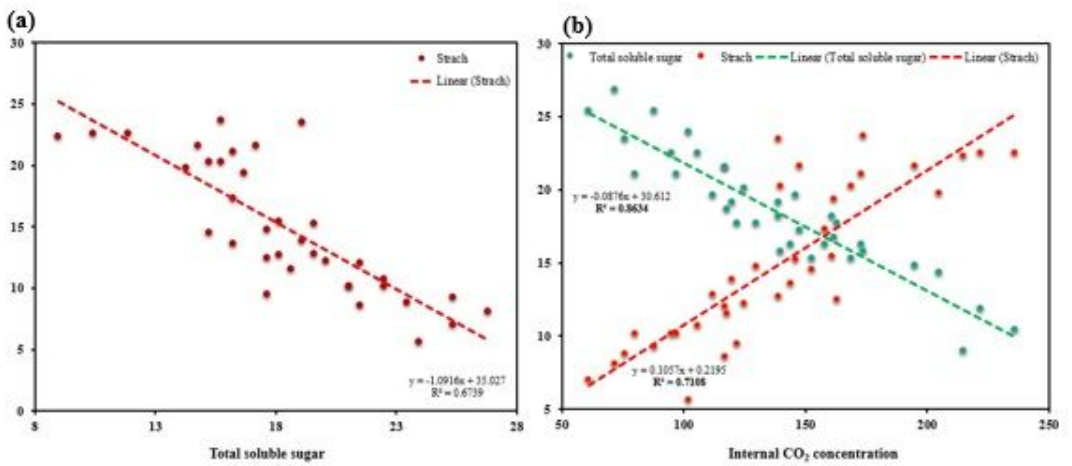

\section{Figure 9}

Plots represention the relations of (a) starch with total soluble sugar, (b) total soluble sugar, starch and internal CO2 concentration in 3 weeks old rice seedlings.

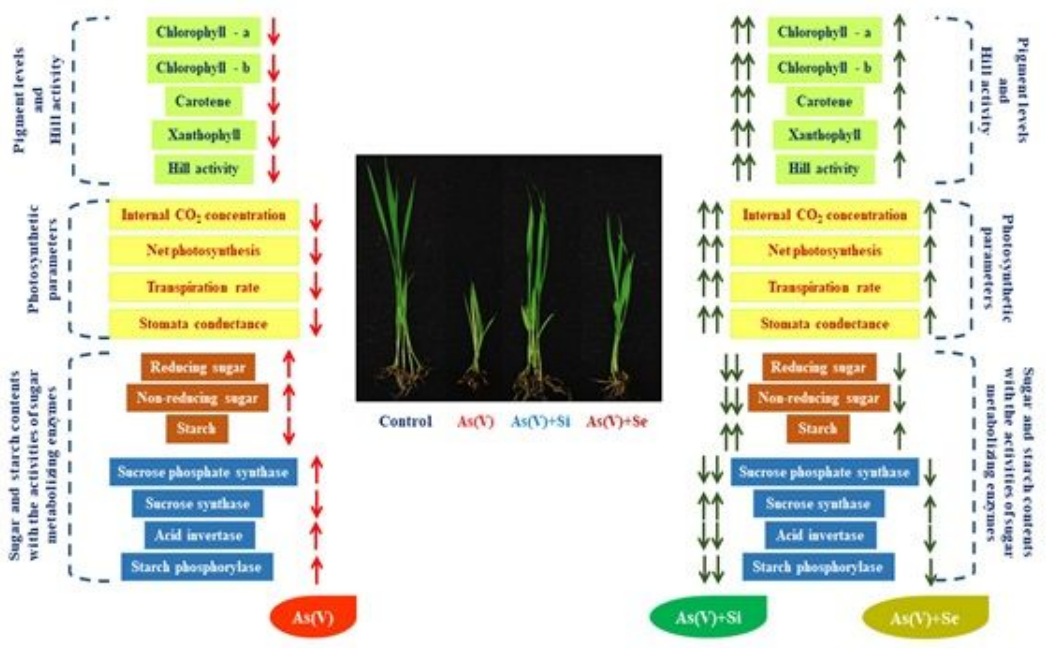

\section{Figure 10}

Schematic representation of Si/Se mediated alterations of chloroplast pigments levels, photosynthetic attributes and carbohydrate metabolism in rice seedlings.

\section{Supplementary Files}

This is a list of supplementary files associated with this preprint. Click to download.

- SupplementaryfileTableS1.xlsx

- SupplementaryfileTables2.docx 